\title{
Built structures in rockshelters of the Pilbara, Western Australia
}

\author{
Lynley A. Wallis ${ }^{1,2^{*}}$ and Jacqueline Matthews ${ }^{2,3}$ \\ ${ }^{1}$ Nulungu Research Institute, The University of Notre Dame Australia, \\ PO Box 2287, Broome, Western Australia 6725, Australia. \\ 2 Wallis Heritage Consulting, 1/b Swan Street, Brighton, South Australia 5048, Australia. \\ ${ }^{3}$ Archaeology (M257), School of Social Science, The University of Western Australia, \\ 35 Stirling Highway, Crawley, Western Australia 6009, Australia.
}

*Corresponding author: Iynley.wallis@wallisheritageconsulting.com.au

\begin{abstract}
Built structures in rockshelters are relatively common archaeological features in the Pilbara that have been neglected in the published literature. Drawing primarily on grey literature, coupled with new data from recent investigations, this paper provides a review of current knowledge about these enigmatic structures. Results show that these features are found across the Hamersley Plateau, although are especially abundant in the Packsaddle Range, and in the Chichester Ranges. Most are likely to be late Holocene features, concurrent with a suite of other changes that occurred during that period. The current practice of grouping all built structures in rockshelters into a single site type (i.e. '(hu)man-made structures') conceals wide variation amongst them. A typology is suggested based on morphological and contextual features to allow better characterisation of these features, thereby improving understandings of their distribution and functions, and facilitating more adequate assessments of their significance in management contexts.
\end{abstract}

KEYWORDS: Indigenous, Archaeology, Built Environment, Holocene, Arid Zone, Stone Structures

\section{INTRODUCTION}

So-called 'built structures' (aka 'walled structures') in rockshelters are a notable component of the archaeology of the Pilbara region of Western Australia (WA). These features are typically categorised by the Department of Aboriginal Affairs (DAA) in the '(hu)man-made structures' site category, defined as, 'The placement or arrangement, by Aboriginal people, of stone, wood or other material made into a structure for ceremonial or utilitarian purposes'. Depending on their assumed or known function, they can also be covered by the DAA definition for a 'repository/cache', this being 'A place were [sic] cultural or utilitarian objects are/were taken, or stored, by Aboriginal people, either past or present'. Structures ranging from single standing stones, to complex stone arrangements in open contexts, to rock piles in both open and closed contexts, through to expanses of rock walling of varying heights and lengths built in rockshelters, all fall within the definition given for a (hu)man-made structure. This paper is only concerned with structures built of stone that occur in rockshelter contexts.
As Comtesse and Harris (2008: 26) noted, built structures in rockshelters present several research questions of interest:

- What is the antiquity of these structures?

- Does their appearance correspond with any other changes observed in the archaeological record?

- Are they linked to either use of the Hamersley Plateau as a refuge during the Last Glacial Maximum or intensification in the late Holocene?

- What are the methods of their construction? and,

- What function(s) did they serve?

Despite their relatively common occurrence and potential for research, built structures have received surprisingly little attention in the literature. Early systematic overviews of stone structures in Aboriginal Australia by Mountford (1940) and McCarthy (1940) made no reference to the Pilbara built structures. Neither did Memmott's (2007) more recent continental review of Aboriginal architecture (though he did describe stone-walled hunting hides, bird hides, housing and 
windbreaks from other parts of the country [Memmott 2007: 184-205]). With one notable exception — that by Bindon and Lofgren (1982) — most accounts of built structures in Pilbara rockshelters are found in unpublished consulting reports. Any discussions of these features in such accounts are inevitably hampered by the lack of access to knowledge about similar sites in adjacent areas.

In order to address the dearth of published information and to consider the research questions posited by Comtesse and Harris (2008), this paper reviews current knowledge about built structures in rockshelters in the Pilbara. It is primarily based on unpublished consultancy reports, and includes new data from recent investigations into two such features in the Packsaddle Range that directly address the question of their antiquity.

\section{DISTRIBUTION}

More than 25 years ago, Brown (1987: 46) suggested that built structures appeared to be more common in the Packsaddle Range in the central Pilbara than elsewhere. While subsequent research has demonstrated some truth to this statement (e.g. Comtesse and Harris 2008: 18; Haast n.d.; Huonbrook Environment and Heritage [HEH] 2012a, 2012b), it is now apparent that these features also occur well beyond the Packsaddle Range right across the Hamersley Range and into the Chichester Range (e.g. Jackson and Di Lello 2003; Jackson and Martin 2000; Mattner et al. 2014; Slack 2008; Westell and Wood 2012, 2013, 2014).

Using site location data provided directly by DAA and BHP Billiton Iron Ore (BHPBIO), the distribution of built structures in rockshelters is shown in Figure 1, demonstrating their presence across the Pilbara. It is acknowledged that these figures are unlikely to be comprehensive for various reasons, and also that repositories/caches are also likely to be severely underrepresented given the tendency of consultants to use the more generic (hu)man-made structure category. However, the available data are adequate to describe the general distribution of these features ${ }^{1}$.

\section{FUNCTIONS}

A characteristic of many reports describing built structures is the limited discussion about their potential function(s). Part of the reason for this is their lack of mention in ethnographic accounts of the Pilbara (e.g. Withnell 1901), though Bindon and Lofgren (1982: 123) noted that this was likely in part to be due to an overall lack of ethnographies in the region generally ${ }^{2}$, rather than this site type being neglected in ethnographies per se. To address this dearth of information, in the section below we systematically consider the range of functions that built structures in rockshelters may have served, including as animal habitats, hunting devices, caches, burial chambers and 'home improvements' (incorporating such options as steps, ladders, windbreaks, fences etc.), as well as for spiritual/ religious purposes.

\section{ANIMAL HABITATS AND HUNTING DEVICES?}

The most detailed published investigation thus far of Pilbara built structures, with the most considered discussion of function - and the one that is cited most often by others - is that by Bindon and Lofgren (1982) of Packsaddle Range site P4349. This particular site contained four walled chambers, the walls comprising flattish $30 \mathrm{~cm}^{3}$ slabs of locally available banded iron formation (BIF) laid atop each in 'random jointing patterns' that were one slab wide (Bindon and Lofgren 1982: 115). Based on this structure, Bindon and Lofgren (1982: 115) concluded the walls 'were not intended to completely seal the area enclosed behind them'. Hollow tree trunks measuring c. 50 x $10 \mathrm{~cm}$ were placed horizontally in some walls so as to penetrate them, while other walls had one or two slabs apparently deliberately missing to allow openings. The area behind the wall they dismantled was too small to enter, and its floor was c. $40 \mathrm{~cm}$ higher than the rest of the shelter and covered with 'fist-sized' rocks that had fallen from the walls and ceiling, along with twigs and spinifex, atop which was a spear. Bindon and Lofgren (1982) noted that there were other walls in rockshelters in the immediate area, but none of those were investigated.

In speculating on the uses of these walled chambers, Bindon and Lofgren (1982) argued that they were likely related to better procurement of animal resources:

... fissures and niches were walled to encourage habitation by small game and perhaps to aid in making their capture more certain. In our interpretation the walls can be regarded both as a hunting device and as a strategy to increase the resource potential of the area (Bindon and Lofgren 1982: 123).

Thus they argued that walled chambers provided favourable habitats for a range of animals, such as rats, possums, pythons and goannas, and made their locations predictable, facilitating a reliable food source that might potentially be related to the use of the region for ceremonial gatherings.

\footnotetext{
${ }^{1}$ Ken Mulvaney (personal communication to LW 22 February 2016) advised that the Rio Tinto internal database does not distinguish between rockshelters containing built structures and those with other sorts of archaeological remains, and so data on such sites in Rio Tinto tenements were unable to be included in this figure.

${ }^{2}$ They referred to a manuscript in preparation by Clarke and Clarke that had some contemporary accounts that mention built structures in rockshelters, but no further information was given and we have been unable to track down the cited manuscript.
} 


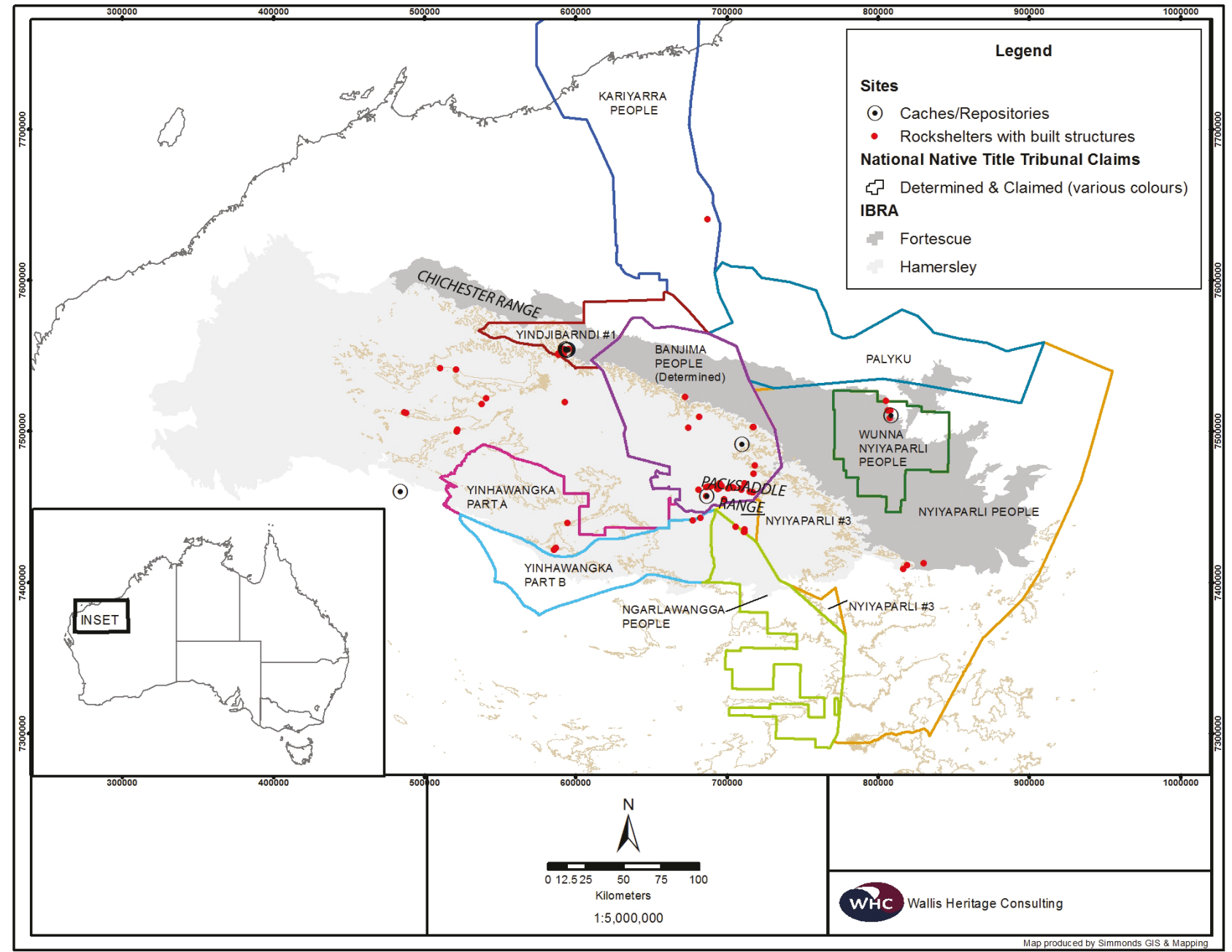

FIGURE $1 \quad$ Map showing the location of rockshelters containing built structures in the Pilbara (based on data provided by DAA and BHPBIO).

The notion of built structures serving to make the task of finding prey more predictable finds some support in a statement by Kimber (1982: 14), who noted that wet weather shelters containing "rough entrance "walls":

... appear to have made certain of the caveshelters more appealing to euros (hill kangaroos) or wallabies. Thus Walpiri men have, during the 1970's [sic], kept such favoured shelters in mind when on hunting expeditions.

The argument that built structures possibly served as animal habitats is commonly cited in consulting reports, but has received little critical consideration. One exception to this is a recent unpublished report by Haast (n.d.) who undertook a desktop study of 30 built structures occurring within BHPBIO project areas, focused on linear structures positioned to block entrance to, or to conceal areas within, a rockshelter. Only $30 \%$ of the structures she considered were located at a rockshelter entrance and, of those, most 'did not contain artefacts and ... are located on a ... severe slope', features that Haast (n.d.: 18-19) considered 'would be expected in areas used to create animal habitat'. Results further indicated a tendency for rockshelters containing built structures to face west, an aspect that Haast (n.d.: 18) argued would be favoured by cold-blooded animals (such as reptiles) seeking to regulate their body temperature. As such, Haast (n.d.: 20) concluded that, in line with Bindon and Lofgren's (1982) hypothesis, habitat creation was most likely the function of linear structures built either within or at the entrance to rockshelters. However, east (or even south) facing rockshelters would provide access to the morning sun, therefore allowing reptiles to warm up and become active earlier in the day, and would presumably have been favoured rather than west facing shelters if habitat creation was their purpose.

Further, given the abundance of hundreds, if not thousands, of rockshelters and many more small crevices/ niches that without any human intervention already serve as animal habitats, the argument that walls were built to construct more such habitats is somewhat unsatisfying, especially as there was no long term way of ensuring that animals would use humanly constructed niches in preference to those that were naturally available (although in the short term baiting may have been an option). This is not to say that such a use was never 
possible, but that this explanation is inadequate or inappropriate in many instances. In this particular instance, various ethnographic accounts from elsewhere in the arid zone routinely refer to spinifex being used as padding (Pitman and Wallis 2012), and its deliberate placement along with the presence of a spear in site P4349 seems more in keeping with that particular built structure being used as a cache, contrary to Bindon and Lofgren's (1982) conclusion. As such, a more detailed consideration of the specific evidence in each situation is required.

Walled structures located at the front of shelters might potentially have served as hunting hides. In his review of Australian stone arrangements, Kimber (1982: 12) described 'low stone-walled structures, large enough for a person to lie in or crouch behind and be well hidden', these were usually $0.5-0.7 \mathrm{~m}$ in height so that spears could be thrown from behind but not accidentally caught on the wall as they were being lifted to be thrown. However, Kimber (1982) did not mention their occurrence in rockshelters or in the Pilbara itself and such hunting hides were typically in open contexts, close to water or animal pads. Darrell Lewis (1988; pers. comm. to LW 2012) and Mulvaney (1993) described similar structures from the Victoria River District (see also Gara 1984 as cited in McDonald and Veth 2009: 53; Memmott 2007; O’Connor 1987; Vinnicombe 1987). None of the known examples of built structures in Pilbara rockshelters match these descriptions and their positioning makes it highly unlikely they functioned as hunting hides per se, though they might, as Bindon and Lofgen (1982) allowed, have been a 'hunting device' (see also the discussion of the PIL_5841 case study).

\section{CACHES?}

Given that one of the P4349 chambers contained a cached spear, what evidence is there that other built structures in Pilbara rockshelters may have served as caches?

Strano and Pervan (2014) recently deconstructed nine built structures - predominantly comprised walls sealing small alcoves, though there was one wall sealing a main entrance - in rockshelters in the Packsaddle Range and found no associated cultural material behind any of the structures. However, in $13 \%$ of the linear built structures that Haast (n.d.) reviewed, artefactual material was found behind the structures although she did not specify what the concealed materials were ${ }^{3}$. As such, she concluded that a caching function for 'at least some' linear built structures in the Packsaddle Range was possible, though it was not a 'primary function' (which, as noted earlier, was concluded to be as animal habitats).

A good example of a built structure with a definite cache function is shown in Figure 2, from the PIL_2258 rockshelter in the Packsaddle Range. The excellent structural integrity of this feature allowed Banjima representatives to demonstrate the presence of what they termed a 'window' stone that could be removed to allow access to an interior chamber in which materials could be stored. In this instance nothing remained inside the chamber, but the Banjima representatives had no doubt that this had been its main function - the absence of cached material did not preclude this interpretation. One of the case study sites presented below, PIL_6000 (also in the Packsaddle Range), also clearly had a caching function.

As at least some of the built structures of the Pilbara functioned as caches, we might consider the types of materials they may have contained. The Newman rockshelter (P2055) was originally recorded by Clarke and Smith (1979) and subsequently excavated in 1980 by Troilett (1982). P2055 contained a stone 'arrangement' in its western chamber, within the loose sediment of which were four stone cores. As such, Brown (1987) interpreted it as possibly having functioned as a cache. No other reports from the Pilbara have yet been found of instances where lithic raw materials have been cached in such a manner.

Perishable foodstuffs (e.g. seeds) and/or organic raw materials might also have been cached behind or in built structures. The Pilbara is one of the few regions in Australia where ethnographic accounts suggest spinifex seeds may have been occasionally utilised as a food source (Pitman and Wallis 2012), while the exploitation of Acacia seeds is well documented (e.g. Juluwarlu Aboriginal Corporation n.d.; Moore 2005; Olive 1997). However, the inability to deter mice and other rodents from entering built structures would possibly preclude effective caching of seeds therein unless they were cached in a specific fashion designed to deter such predation.

Beyond seeds, a passage from one of the few ethnohistorical sources for the Pilbara may be of direct relevance. Emile Clement, a German ethnographer/ collector who travelled along the northeast margin of the Hamersley Plateau during 1896-1898, described an account of meat being dried:

Should there be a very great supply of meat, they sun-dry it, especially if they are on the point of going on a long journey in shifting their camp or hunting-ground. The sun dries the meat as hard as a bone. Before use, it is steeped in water, pounded between stones and eaten (Clement and Schmeltz 1903: 3).

This tantalising glimpse into the possibility that dried meat could also have been stored in built structures, especially those situated in dark cool caves, is further supported by contemporary Kuruma Marthudunera traditional knowledge. Recounting information provided

\footnotetext{
${ }^{3}$ Further, she noted that in many cases the walls had not been deconstructed and so it was not known whether anything was once cached behind them, and therefore this figure may be under-representative.
} 


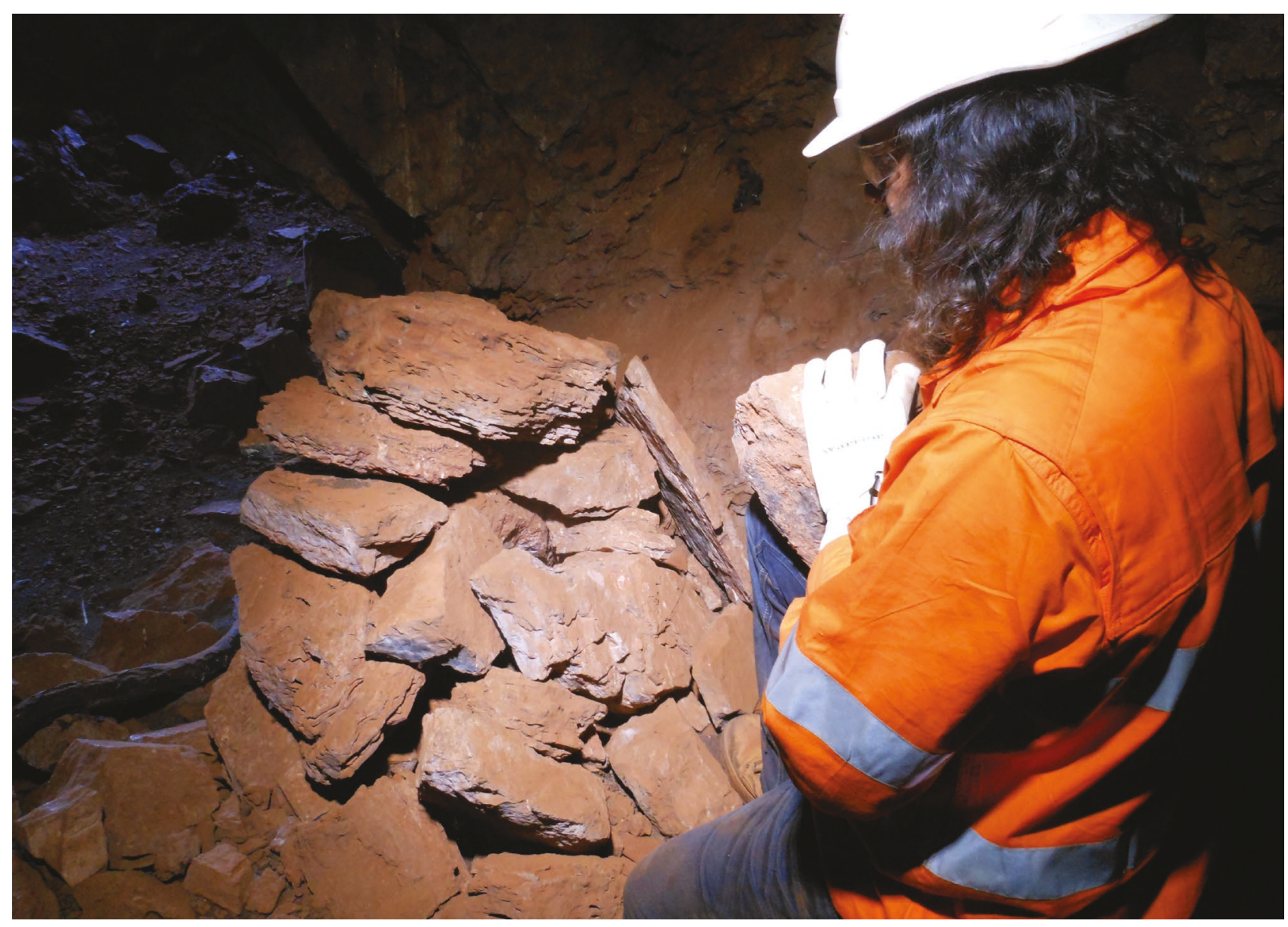

FIGURE 2

The built structure in PIL_2258 that served a caching function, with Banjima representative Yuddy Butler holding the 'window' stone allowing access to the interior chamber.

to him by other Kuruma men, specifically Gordon Lockyer and Algy Paterson, Brendon Bobby (pers. comm. to LW Dec 2015) recalled the practice of drying entire goannas that could subsequently be pounded up and eaten (see also Brehaut and Vitenbergs 2001: 116). Likewise, he advised that strips of flesh could be cut from a kangaroo and dried on rocks in the sun. The dried meat was then placed on a yandi (coolamon), covered with spinifex, and subsequently concealed with rocks to protect it from predators for periods of 4-6 months. When required, the meat, which had the texture of jerky, could be eaten as is, or rehydrated and pounded into a 'damper-like' meal. Brown (1987: 17) also reported food and personal equipment historically being stored in rockshelters, with 'walls' being constructed to keep dogs out. Given the unfavourable preservation conditions for organic materials in Pilbara rockshelters, dried meat or any other perishable foodstuffs or raw materials are unlikely to be found routinely in built structures today, though recent advances in ancient DNA analysis as well as phytolith analysis (cf. Wallis 2001, 2003) might allow the testing of sediments within built structures to determine the prior presence of now long-gone foodstuffs or other organic materials.

Other items that might have been stored in built structures in rockshelters could include ceremonial paraphernalia, where concealment may have been just as important as physical protection. Aboriginal groups of the arid zone had a decentralised religious structure accompanied by a rich material culture (Berndt 1974; Smith 2013: 217) and ceremonial items were reportedly placed in niches or caves for their protection:

In each Oknanikilla or local totem centre, there is a spot called by the natives the Ertnatulunga. This is, in reality, a sacred storehouse, which usually has the form of a small cave or crevice in some unfrequented spot amongst the rough hills and ranges which abound in the area occupied by the tribe. The entrance is carefully blocked up with stones so naturally arranged as not to arouse suspicion of the fact that they conceal from view the most sacred possessions of the tribe (Spencer and Gillen 1927, see also 1899 and 1904). ${ }^{4}$ 
Similarly, and with specific reference to the Walpiri people, Kimber (1982: 16) noted that 'the retrieval of sacred objects from a sealed-off crevice resulted in the stone used in the sealing-off being stacked neatly near the entrance'. Kimber (1982: 15) also noted the use of stone 'heaps' in eastern Aranta and Pintupi Country 'as protective covers for sacred objects: great care is used in the removal — and later replacement — of the covering stones when the objects are viewed'5.

Tindale (1974) suggested that Western Desert lore had become highly influential in the Pilbara region in the last few hundred years, with social influences moving east to west (see also Gibbs and Veth 2002: 17; McDonald and Veth 2013). Although rock art studies indicate that the Pilbara had a distinctly different graphic system compared to that of the Western Desert (Smith 2013: 241), the rock art of the margins of the Western Desert shows influence from the Pilbara (Smith 2013: 259). A recent study of the painted art of the central Pilbara by Wallis et al. (2015a, 2015b) also suggested that there are shared elements between the Western Desert and central Pilbara motif repertoires. As argued by McDonald and Veth (2013), rock art was used to negotiate broad-scale and local group identities, with a decrease in petroglyph production and an increase in the construction of stone arrangements at aggregation locales. A key component of the evidence on which McDonald and Veth (2013) based their argument was the increase in intensity of site use (more sites being occupied and an increase in artefact discard rates in occupied sites) (e.g. Comtesse and Harris 2008; HEH 2013), along with the appearance of stone arrangements (cf. Hook and Di Lello 2010). The abundance of stone arrangements in the Packsaddle Range has also led some to argue that it was a 'travelling through' area (Brown 1987; Comtesse and Harris 2008), linked to the carrying out of ceremonial activities (though this may also be in part an artefact of the number of surveys undertaken in the local area). Following this line of argument, it is possible that at least some of the built structures, particularly those of a free standing cairn type (such as those seen in PIL_6000 and PIL_2258) and/or those that seal small crevices/niches, may be associated with the protection of ceremonial objects that were not to be seen by uninitiated people (Brehaut and Vitenbergs 2001: 8).

\section{BURIAL CHAMBERS?}

Some of the built structures in the Pilbara could also relate to burial traditions, whereby they served either as primary or secondary interment sites. Unfortunately, limited information is available about traditional burial practices in the inland Pilbara. Clement and Schmeltz
(1903: 8) described the manner of northwest Australian funerary rites as follows:

The body is either carried upon the hill tops, where it quickly mummifies or is placed in a shallow grave in a sitting posture. Some tribes place the dead on trees or in hollow tree-trunks. After some time, if the deceased was a man, the widow takes the thigh-bone and carries it about with her for several years and some of the smaller bones are secured by the relatives, especially if the departed was a great hunter.

This account is corroborated by Daisy Bates, who recorded that, in the Pilbara, some corpses were placed in rockshelters until they had become skeletonized, after which relatives took away several of the smaller bones which they carried for some time (White 1985: 308309). She also noted that in some instances secondary burial of the larger bones and skull might occur in rockshelters or 'under boulders'. Brehaut and Vitenbergs (2001: 40) recounted burials occurring in caves, after which 'the opening would be closed with stones and a small stone cairn outside usually marked the site'.

Archaeologically, there are limited data about such practices. When recording a walled rockshelter near the Brockman Detritals Mine, Jackson and Di Lello (2003: 16) reported that Gurama elders had suggested to them that walled structures may have been used to protect burials but they were unable to positively confirm this. Likewise, in the central Pilbara Wallis et al. (2015a, 2015b) recorded a large rock pile (measuring c. $3 \mathrm{~m}$ in length by $1 \mathrm{~m}$ in width by $0.75 \mathrm{~m}$ in height) against a wall in a rockshelter marked by a nearby scarred tree, with two additional small walled structures sealing small niches in close proximity. Upon viewing this site the Banjima representatives present advised that the large structure was a burial, an assessment not inconsistent with its morphology, though no human bones were observed (Figure 3). Bindon and Lofgren (1982: 116) noted the 'complete lack of human bone fragments or appropriate cultural material together with the absence of any of the usual markers ${ }^{6}$ excluded the built structures they examined at P4349 as having served as burial chambers.

To date, no published accounts of built structures protecting confirmed burials in the Pilbara are available; such reports are typically confidential (e.g. Bunting and Lantzke 2007) and not easily accessed, and it is therefore not possible to confidently assess how widespread such practices may have been. If burial behind stone walls, under rock piles or as secondary interments in cairns was practiced throughout the Pilbara, as Brehaut and Vitenbergs (2001: 42) described occurring in the

\footnotetext{
${ }^{5}$ This suggests that haphazard arrangements of stones near built structures would be more likely to be the result of inquisitive Europeans or the effects of decay through time than Aboriginal activity.

${ }^{6}$ Though they did not specify what the 'usual markers' would be.
} 


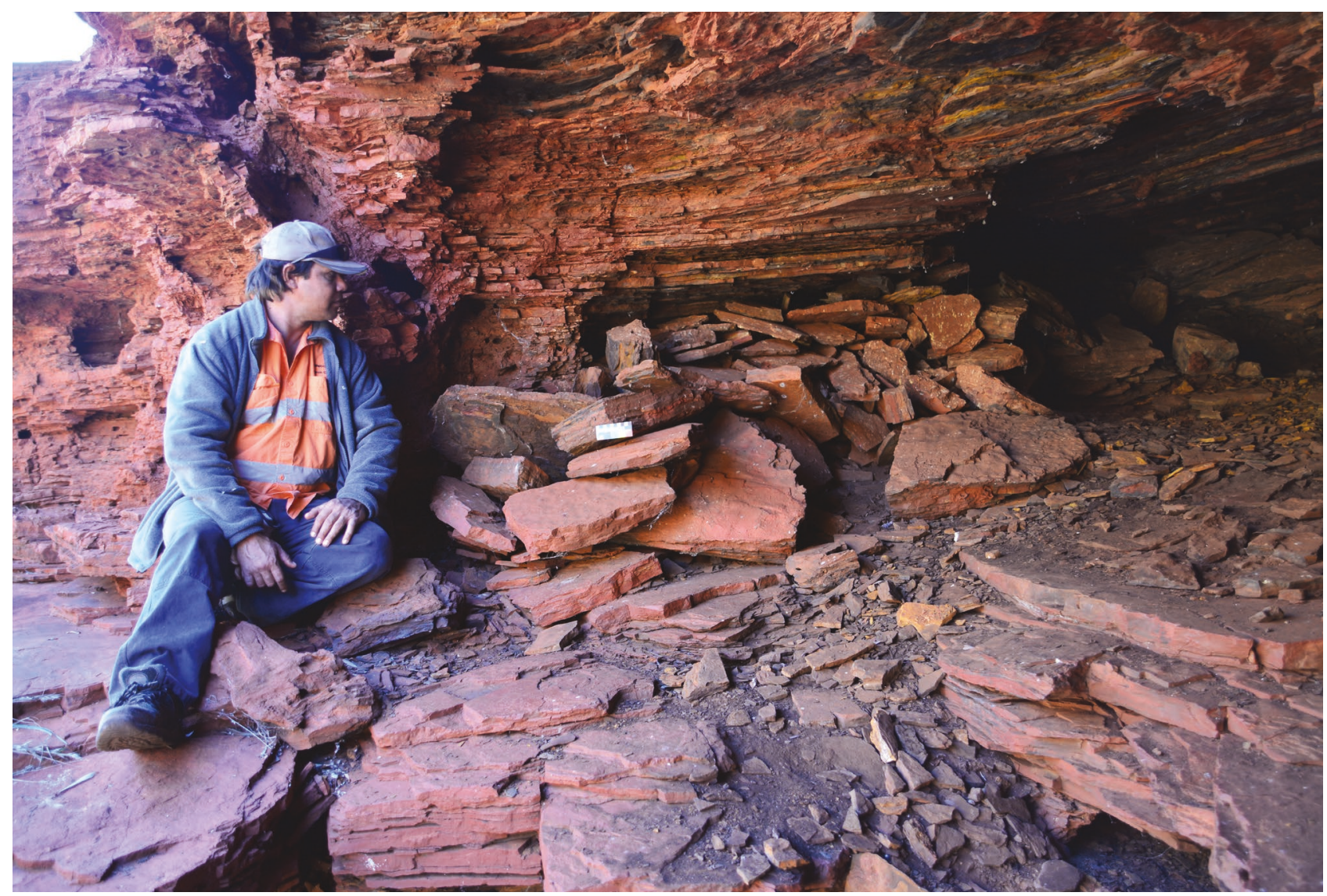

FIGURE 3

A built structure in the Dowling Springs gully that may have served as a burial, with Banjima representative Paul Ryan seated.

ranges where digging a grave was difficult, it seems that this practice was not done as frequently as in the Kimberley and Arnhem Land regions, where interment in rockshelters was common practice?

If structures were built to protect burials, it might be less likely that people would have inhabited such sites, and thus a lack of occupation evidence might be expected, though this is dependent on the specific beliefs of people which can vary considerably throughout time and geographically. Offering some support to this notion, Haast (n.d.: 22) noted that many rockshelters containing built structures amongst her study sample possess 'no other archaeological features except the walls' and, those sites with walls and artefacts, had 'limited evidence for occupation or other ceremonial practices such as rock art' (Haast n.d.: 20).

\section{HOME IMPROVEMENTS?}

Another possible function of some built structures that has not been well expressed or discussed in the available literature is a category loosely grouped here as "home improvements'. The concept of moving rocks to make a rockshelter more habitable was first proposed by Kimber
(1982: 14), who noted that wet weather shelters:

... may incorporate what appear to be stone arrangements. At the entrance to some of the shelters are rough lines or piles of stones. Such a line does not denote a protective device, but instead marks the line of cleaning of the inner area to allow both greater comfort and more room.

As such, some built structures may have been a byproduct, rather than the intended outcome, of deliberate human activities. However, the extensive nature and careful construction (forming deliberate walls rather than haphazard piles) of some built structures, and the abundance of rocks still remaining on the shelter floors in other examples, counts against this explanation in many instances.

Mulvaney (1996: 13, 17) also recounted Mirriuwung and Gadjerong information about the construction of a stone barrier along the front of a rockshelter to keep the water out during a heavy rainstorm in the 1930s. $\mathrm{He}$ noted such features were not uncommon in the region, and were known in the Mirriuwung language as karltonjaldi, literally meaning 'stone-breakwater' (Mulvaney 1996: 13). Given the severe rainstorms 
associated with cyclonic activity that occur seasonally in the Pilbara, it is possible that some stone structures near the front of Pilbara rockshelters could have served similar purposes.

Based on their own experiences with native wildlife during fieldwork, Comtesse and Harris (2008: 151) suggested that built structures sealing crevices may have been 'preventative measures ... to ensure safety from reptiles and insects while the front of shelters were utilised for sleeping, resting and maintenance activities beside a fire'. However, this proposition seems unlikely as crevices could not be entirely sealed, and, as Comtesse and Harris themselves discovered, they attracted, rather than repelled, reptiles and insects. Further, this is a very Eurocentric view of what comprises a suitable habitation site, since some insects, such as bees, were a useful addition to a site because of the resources they provided.

Jade Pervan (pers. comm. to LW 2014) suggested that some built structures may have been constructed to prevent infants from inadvertently crawling into dangerous crevices. Given the lack of any other obvious explanation and the absence of cached materials behind many built structures, this argument seems logical and offers a more nuanced and gendered perspective on the Pilbara archaeological record than has previously been advocated. This is a hard hypothesis to test, however, though perhaps an association between built structures and rockshelters showing clear evidence of habitation, preferably with seed grinding stones to demonstrate the definite presence of women (and by inference children) would lend weight to it. Nonetheless, if this was a function of built structures, one might question why they are not found in all geographic areas of Australia throughout all time periods.

With broader reference to Central Australia and the Western Desert regions, Kimber (1982: 15) noted that some rockshelters contain rock piles deliberately placed to serve as steps, allowing access to hollows containing sacred objects. This proposition was also argued by Jackson and Fry (2001: 66) for a particular built structure in a central Pilbara rockshelter:

The presence of this cairn feature is consistent with the concept of them functioning as 'step ladders' to facilitate ease of access to overhead features. In this case, a long deep crevice is present just above the dripline and can only be reached by standing on the cairn which is positioned directly below. Birds may have nested in this crevice and people would have used the cairn as an aid in harvesting the eggs or people may have cached items in the crevice.

In the Brockman area of the central Hamersley Plateau (west of Packsaddle) the main forms of built structures appear to be rock piles, typically in the absence of other archaeological material, though some walls erected at the entrances to small (non-habitable) rockshelters or so as to seal crevices within shelters are also known (e.g. Jackson and Di Lello 2003; Jackson and Martin 2000; Slack 2008; Westell and Wood 2012, 2013, 2014). The interpretation of rock piles as steps was considered by Westell and Wood (2014: 56) to be the 'most logical suggestion' as to the function of many such structures in the Brockman region. A review of rock pile positions in the Brockman region was consistent with their being 'constructed where the drip-lines are highest and therefore require scaffolding to access' (Westell and Wood 2014: 56). They do point out that the dripline height above rock piles is rarely recorded and that some rock piles had been 'erected below low accessible drip-lines or where there is no possibility of reaching the shelter ceiling even with the aid of the cairn (e.g. WELT11_14, MTW13_22)' (Westell and Wood 2014: 56). Steps were also the explanation most favoured by Warren (2000) and Dias et al. (2011: 93) for built structures in the MAC-FS14/DAA 17631 rockshelter in the Packsaddle Range. Further afield in the Murchison, wooden scaffolding with stone bases has also been documented at the Wilgie Mia ochre quarry, which provided access to ochre seams (Davidson 1952: 83-84; Smith 2013: 279).

A recent observation in the central Pilbara during an investigation with Banjima representatives revealed two sturdy branches surrounded by rocks that had been positioned in the PIL_2000 rockshelter. Somewhat similar to steps, it is possible that these structures served as 'ladders' allowing access to crevices and hollows in high parts of the rockshelter. Each branch was supported at its base by a series of carefully positioned rocks that ensured the branch did not easily move. If the branch had decayed (or been displaced), the pile of rocks would remain, with little hint as to its original function. Another interpretation of upright branches in rock piles was offered by Banjima elders. When asked about the purpose of such a structure from another previously undocumented rockshelter in the Packsaddle Range, they advised it would have originally formed a windbreak, with the main branch once having been supplemented by numerous leafy branches leaning against it (Wallis and McBride 2015). Other potential support for the use of windbreaks in Pilbara rockshelters can be found in the excavations at rockshelter P5315 in the Packsaddle Range, where Brown and Mulvaney (1983: 56-57, 80) identified a stratigraphic feature they interpreted as a post-hole, suggesting it may have been part of a wind-break or humpy (cf. Gould 1968:112).

Of final relevance here are some ethnohistorical accounts of built structures being used as 'fences' to constrain dingo pups. For example, in the Kimberley region, Love (1936: 176) mentioned such enclosures of stone, and while his examples did not occur in rockshelters, it is possible that some built structures in the Pilbara might have served such a purpose.

\section{SPIRITUAL/RELIGIOUS PURPOSES?}

Haast (n.d.: 20) also acknowledged that built structures, particularly walls, might have served as warning mechanisms to keep people away (or to keep spirits contained within them). While the limited ethnographic accounts directly referring to built 
structures in rockshelters make it difficult to elaborate on this acknowledgement, there are some suggestive mythological stories, such as the Kariera story of Eaglehawk and Crow, which features eaglehawks being sealed up inside a cave using rocks (Brown 1913: 169-170). Elkin (1993: 124) also noted that 'ghosts' and totems could reside in caves. Furthermore, anecdotes from colleagues working with Traditional Owners in the Pilbara are also supportive of spiritually protective functions of built structures (Jillian Barteaux pers. comm. to LW Dec 2015). Clearly there is a need to explore this aspect in greater detail with senior Traditional Owners before going further with interpretations along these lines.

\section{ANTIQUITY}

Unsurprisingly given their predominantly inorganic nature, built structures have proven difficult to date. Most speculation about the antiquity of these features has focused on dates obtained from excavations within the rockshelters in which they occur, as opposed to direct dating of such structures themselves. Unfortunately, such dates only give 'an indication [of] a given period when the rockshelters were occupied and [the built structures] are therefore not likely to have been constructed before this time' (Comtesse and Harris 2008: 150).

On the basis of the associated excavation results from four sites, Brown (1987: 47) tentatively posited that built structures 'are late Holocene features, somehow linked with the increasing use of this marginal environment in late Holocene times'. This proposition seems to be generally well supported by the radiocarbon dates obtained subsequently, though there are some exceptions (Table 1). The PIL_261 excavation recovered a single stone artefact associated with a 23,530 bp date, but no surface artefacts excepting a built structure. PIL_552 contains a Pleistocene archaeological sequence, with a rock wall at the contemporary ground surface. The DAA 22283/22285 (MAC04-06/PIL_542) site, which contains a built structure, was first occupied in the late Pleistocene, though the site was most intensively used in the period $1200 \mathrm{cal}$. BP to the present.

Yet, despite these Pleistocene age determinations, in all instances it seems more reasonable to assume that the current built structures were related to more recent phases of site use. However, this is not to say that now deconstructed stone arrangements could not have existed in an earlier time. Part of the reasoning behind this is the fact that all known built structures occur at the contemporary ground surface, rather than in excavated or partially buried contexts. This strongly suggests insufficient time has elapsed since their construction to allow sediment to build up against their outer, lower levels (though in some instances the structures have served as a sediment trap, allowing some sediment to build up against their inner, lower levels).

The following section presents a case study of two morphologically different built structures in rockshelters in the Packsaddle Range that sheds some light on the issues of their antiquity, as well as function.

\section{CASE STUDY: \\ TWO BUILT STRUCTURES INTHE PACKSADDLE RANGE}

PIL_5841 is a large, high ceilinged rockshelter with two entrances, located at the base of the eastern side of a large cliff, along a north-west to south-east trending gully in the Packsaddle Range (Czerwinski 2013: 26) (Figure 4). The built structure associated with PIL_5841 can be considered as a 'wall', measuring c. $1.2 \mathrm{~m}$ long by $1 \mathrm{~m}$ high by $0.4 \mathrm{~m}$ thick and was positioned in the more

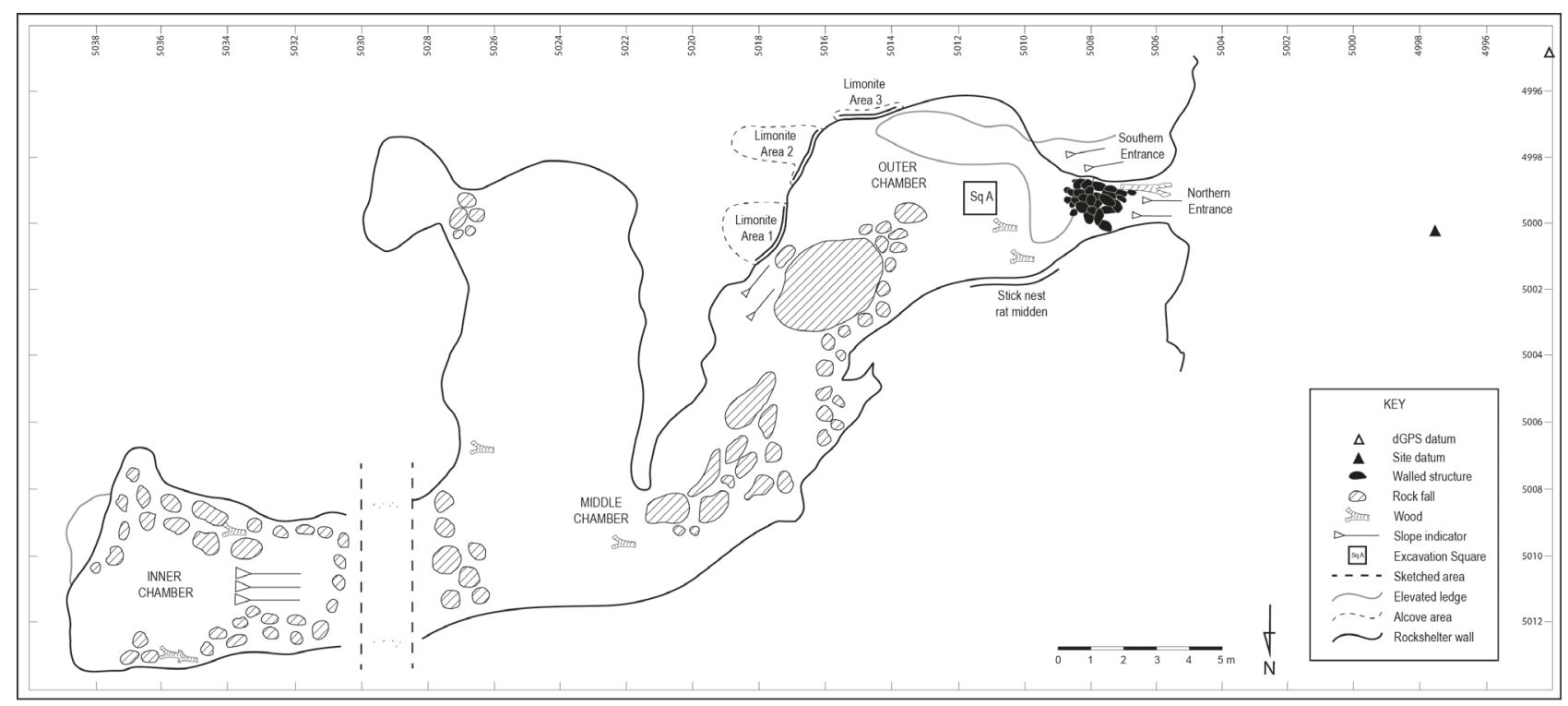




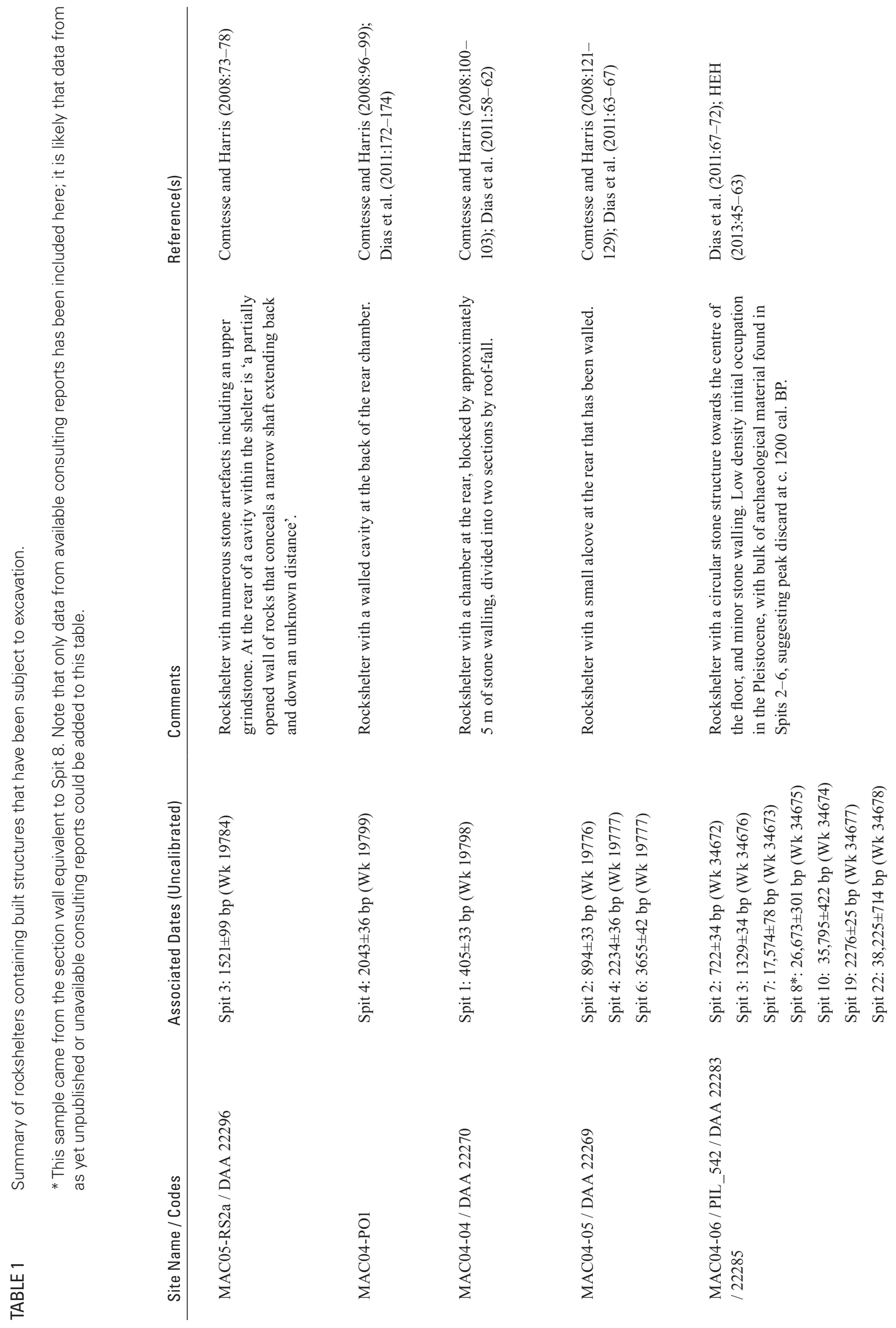




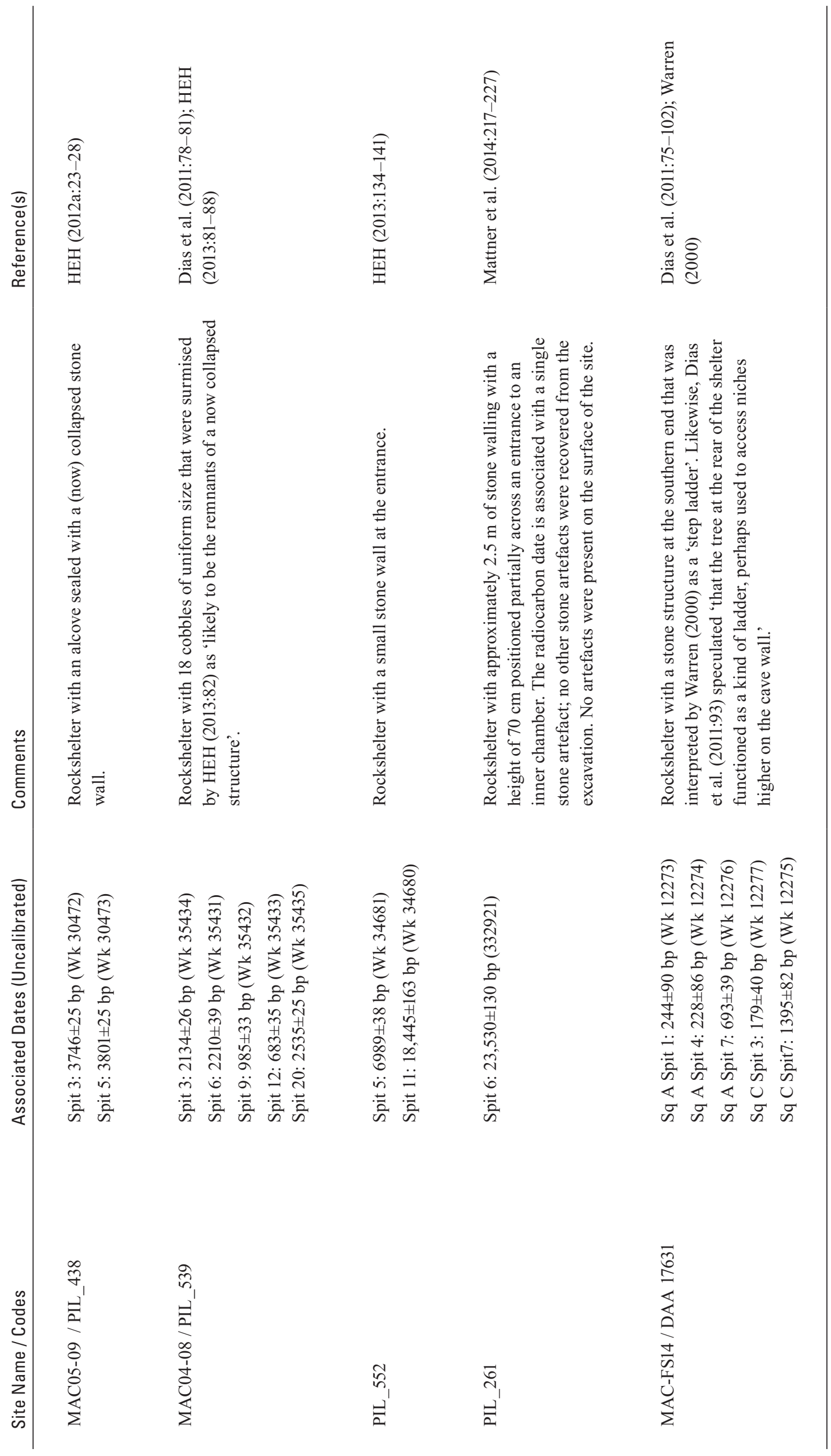




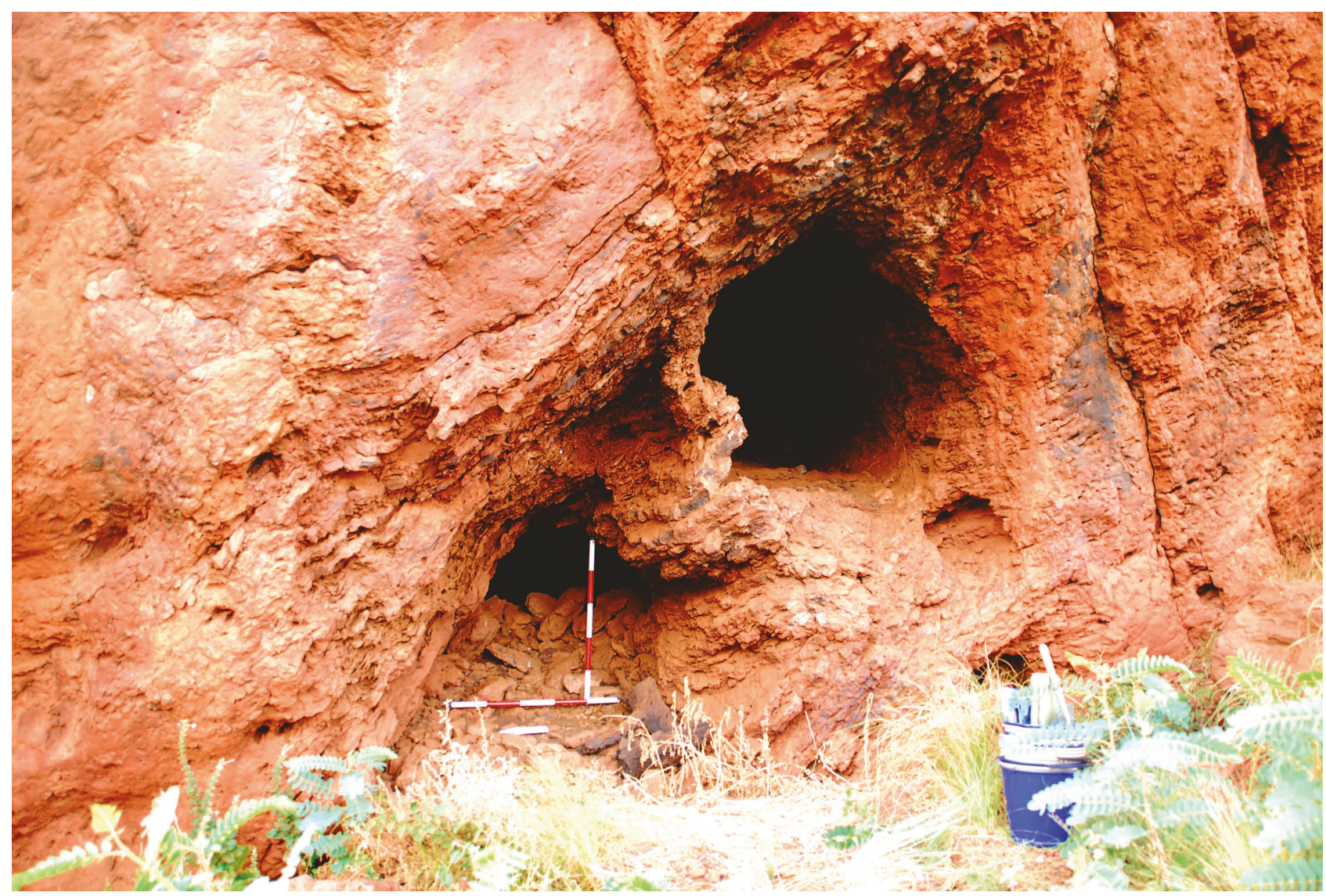

FIGURE 5

View looking west into the PIL_5841 site, showing the built structure in June 2014 prior to deconstruction to the left and the other opening to the right. North is to the left and increments on the ranging poles are $20 \mathrm{~cm}$. The wooden logs near the ranging poles were originally positioned atop the structure (Czerwinski 2013); these were moved by Banjima representatives after the original 2013 recording. During their removal, several of the rocks in the wall were displaced, resulting in the opening above the structure into the shelter appearing larger in mid-2014 than when originally recorded in 2013.

northern entrance so as to prevent access via that means (though access was still possible through the adjacent southern entrance) (Figure 5). Several large pieces of wood had been placed on top of it, though no other artefacts were recorded at the site. As only one entrance to the shelter was walled, Czerwinski (2013: 26) did not consider it likely that the feature was designed to serve as a cache. Inside the shelter are several hollowed out deposits of limonite that were potentially used as a pigment source. Numerous small branches with evidence for burning on one end are scattered across the shelter floor, though there is no charcoal at surface level. Excavation within the main chamber revealed extensive charcoal at depth, with a very low density of stone artefacts.

In contrast, PIL_6000 is a small overhang with a low ceiling height and limited living space, located on the western side of the base of a BIF cliff, approximately $1.25 \mathrm{~km}$ east of PIL_5841 (Czerwinski 2013: 24, 46-47) (Figure 6). The built structure in this rockshelter measured c. $1 \mathrm{~m}$ long by $1 \mathrm{~m}$ high by $1 \mathrm{~m}$ thick, with larger rocks placed at the bottom of the structure and smaller rocks at the top (Figure 7). This structure was

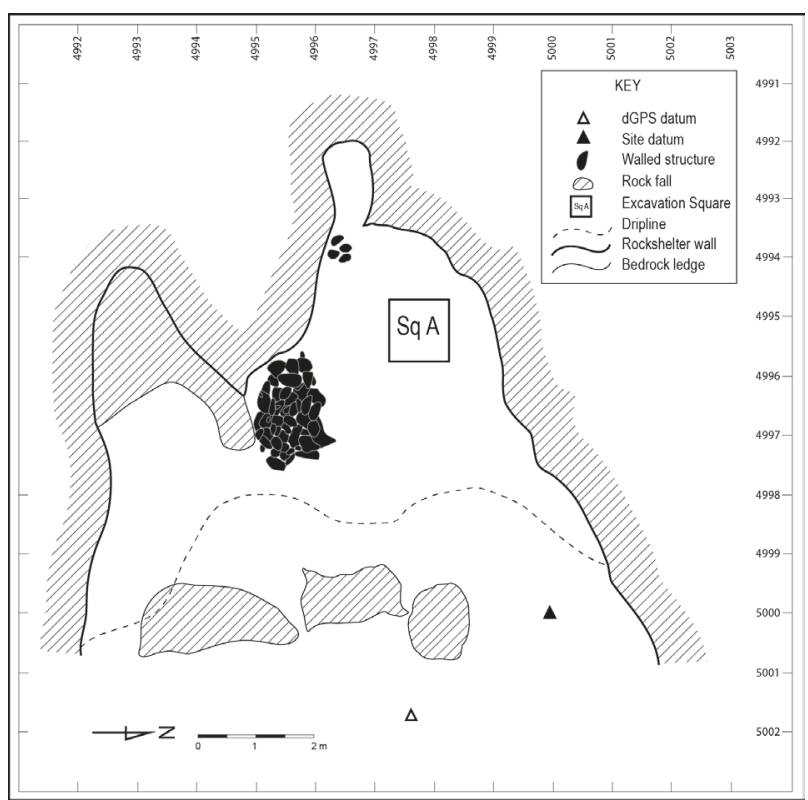

FIGURE 6

Revised site plan for PIL 6000 (based partially on the original site plan from Czerwinski 2013:49). 
positioned under the low ceiling, such that access to it required a person to crawl, kneel, sit or stoop very low. There was some collapse of the upper part of the feature, with no clear window stone apparent. Given its morphology and location, Czerwinski (2013: 24, 46-47) considered that this structure likely functioned as a cache.

BHPBIO requested detailed investigations of the PIL_5841 and PIL_6000 sites be undertaken to attempt to learn more about the functions, antiquity and nature of construction of the built structures in each.

\section{METHODS}

The built structures in each site were investigated through a process of systematic dismantling and recording during mid-2014. Digital photographs were taken of each structure throughout the dismantling process, incorporating reference points whose position was recorded with a total station. Temporary benchmarks were established near each site using a differential global positioning system (dGPS); these were then used to link the total station data and photography.

Before removal, rocks larger than c. $10 \mathrm{~cm}$ in maximum dimension were given a unique, sequential identifier and their location marked on a digital photograph of the structure. Marked up photographs were later coupled with the total station data in a geographic information system (GIS) to create a final digital record of the structures. During total station recording, on each rock a minimum of four points, but more as necessary (up to 20), were taken to capture its morphology. The decision was made only to record rocks larger than c. $10 \mathrm{~cm}$ in maximum dimension as these rocks appeared to form the main structural basis of the built features. To ensure that the integrity of the structure was retained for as long as possible (in order to better understand the construction process), care was taken to ensure that the removal of each rock did not inadvertently cause the movement of adjacent rocks.

After removal, maximum measurements were taken of each rock, including length in any plane, width at right angles to the length, and thickness at right angles to the width and length. Each rock was weighed to the

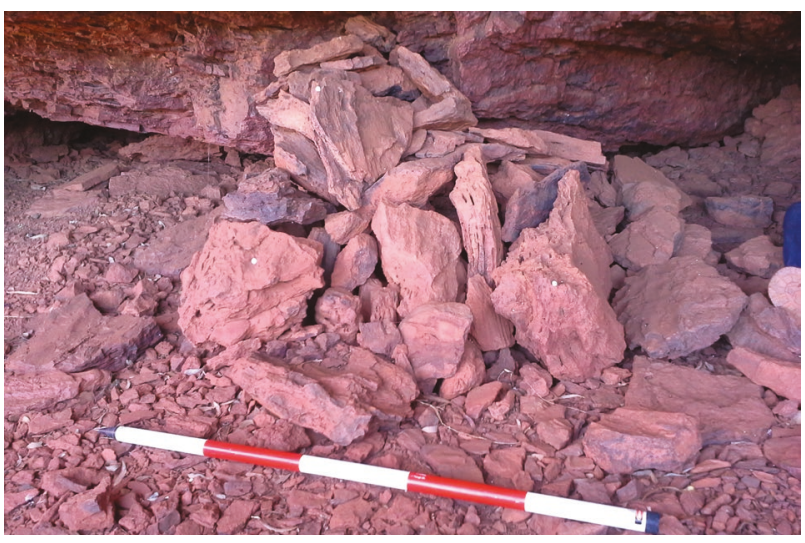

FIGURE $7 \quad$ The built structure in PIL_6000 prior to the commencement of deconstruction in June 2014. Increments on the ranging pole are $20 \mathrm{~cm}$

nearest $0.5 \mathrm{~kg}$, and examined to ascertain whether it possessed any cultural modifications, such as grinding or flaking. On occasion at PIL_5841, the presence of large quantities of small rocks and organic debris amongst the larger rocks necessitated their collective removal; in these instances the material removed was weighed and sieved. The positions of any stone artefacts, charcoal or pieces of wood located amongst the rocks of the walled structures were also given unique identifier numbers, plotted using the total station, and retained for future analysis.

Although it had originally been planned to entirely dismantle each structure, given the extensive nature of the feature in PIL_5841 it was decided only to partially dismantle it, exposing a cross-section of the wall. A total of 59 rocks were removed from across the entire width of the PIL 5841 built structure, reducing its height to the approximate level of the contemporary interior floor surface, before dismantling continued in the central part of the structure only.

Radiocarbon ages presented below were all calibrated using OxCal v4.2 with the SHCall3 calibration curve (Bronk Ramsey 2009; Hogg et al. 2013).

TABLE 2

Summary data for the rocks removed from the PIL_5841 built structure. Note that one stone was too large to be moved and weighed safely so is excluded from the final row of this table.

\begin{tabular}{lcccccc} 
Measurement & Number of Rocks & Mean & Maximum & Minimum & Mode & Median \\
\hline Length (mm) & 106 & 245 & 630 & 114 & 210 & 220 \\
Width (mm) & 106 & 153 & 400 & 10 & 140 & 140 \\
Thickness (mm) & 106 & 80 & 350 & 10 & 50 & 70 \\
Weight (kg) & 105 & 6 & 48 & 1 & 3 & 4 \\
\hline
\end{tabular}




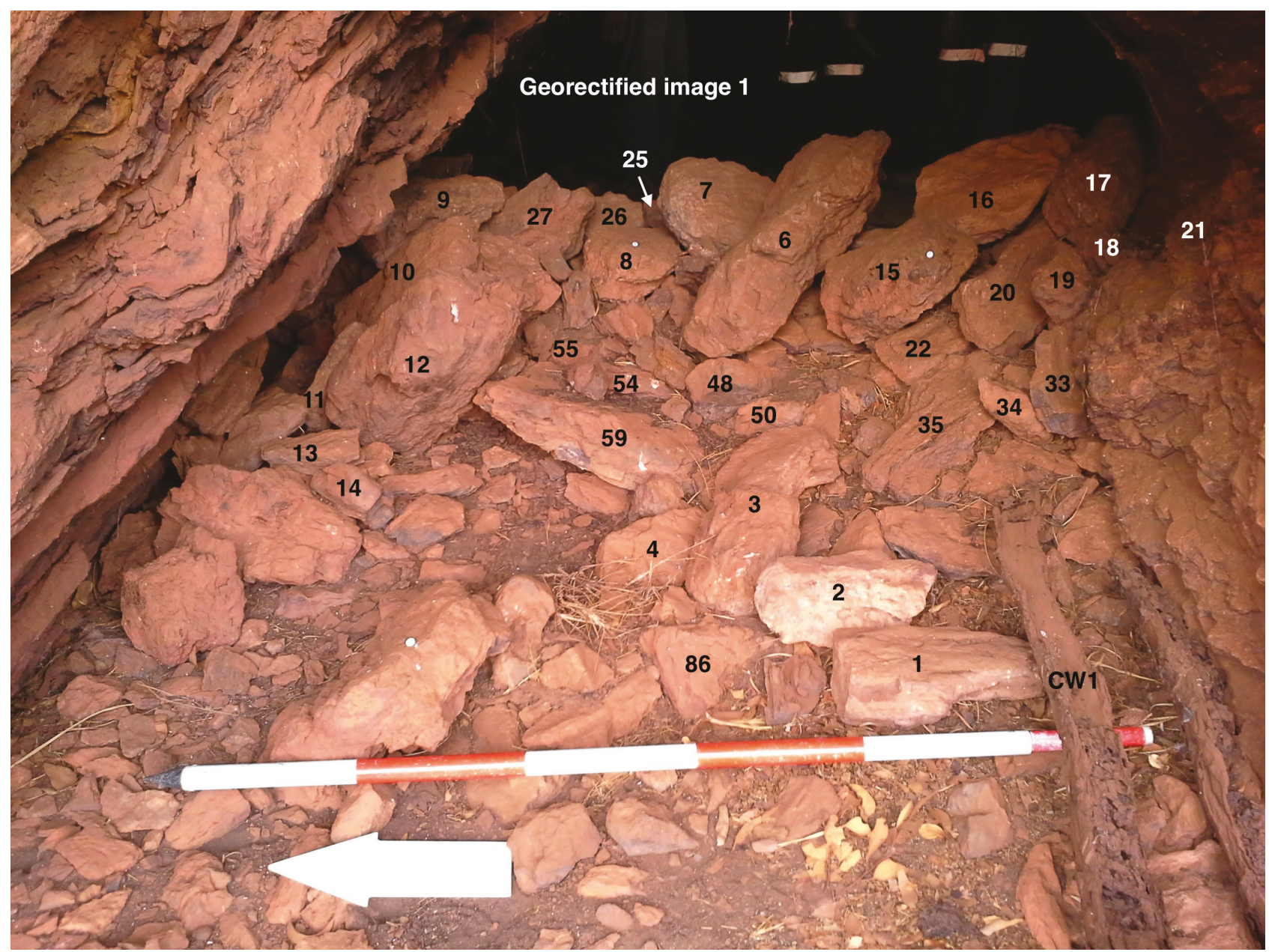

FIGURE 8

The built structure at PIL_5841 at the commencement of dismantling. White arrow indicates north and increments on the ranging pole are $20 \mathrm{~cm}$.

\section{RESULTS}

\section{PIL_5841}

Photographs of the PIL_5841 built structure during dismantling are shown in Figures 8-10.

A total of 106 rocks were removed, summary information about which is presented in Table 2. The largest rock removed measured $630 \mathrm{~mm}$ in maximum dimension, and the heaviest weighed $48 \mathrm{~kg}$. As summarised in Table 2, the average rock measured $245 \times 153 \times 80 \mathrm{~mm}$ and weighed $6 \mathrm{~kg}$; however, the most common rock weighed just half of that, i.e. $3 \mathrm{~kg}$. The larger rocks tended to be in the eastern half of the structure, while smaller rocks tended to occur in the western half. All of the measured rocks were local BIF (from which the shelter is formed) and none showed any signs of cultural modification (though other similar structures have been known to incorporate, seemingly on an ad hoc basis, grinding stones; Fiona Hook and Ben Fordyce pers. comm. to LW Dec 2015).

The restricted size of rocks used to construct this structure demonstrates the builders had a definite preference for rocks that could be easily moved by one person, likely sourced from the roof-fall available elsewhere in the rockshelter. This is what we would hypothesize to be the case with a humanly constructed feature as opposed to a natural feature that mimicked a humanly built structure and which would consist of a random rather than patterned range of rocks. It is also not what would be expected if the structure had formed as a by-product of a floor clearing exercise to make the shelter more habitable. Having said that, the floor is relatively clear of rocky debris, though if the wall was only a by-product of floor clearing, one wonders why people would have expended the effort to construct a 'neat' coursed structure only in the entrance to the shelter, rather than a random pile of rocks. The absence of any obvious hearths at the contemporary ground surface or stone artefacts (excluding a single retouched flake) suggest this shelter was not routinely occupied, and therefore clearing of the floor to improve comfort levels seems improbable.

The spaces between rocks in the parts of the structure above the modern ground surface contained a mass of loose macropod and murid faecal pellets, charcoal, seeds and fragments of spinifex. This material appears not to have been deliberately placed by people between the rocks during construction, but rather to have 


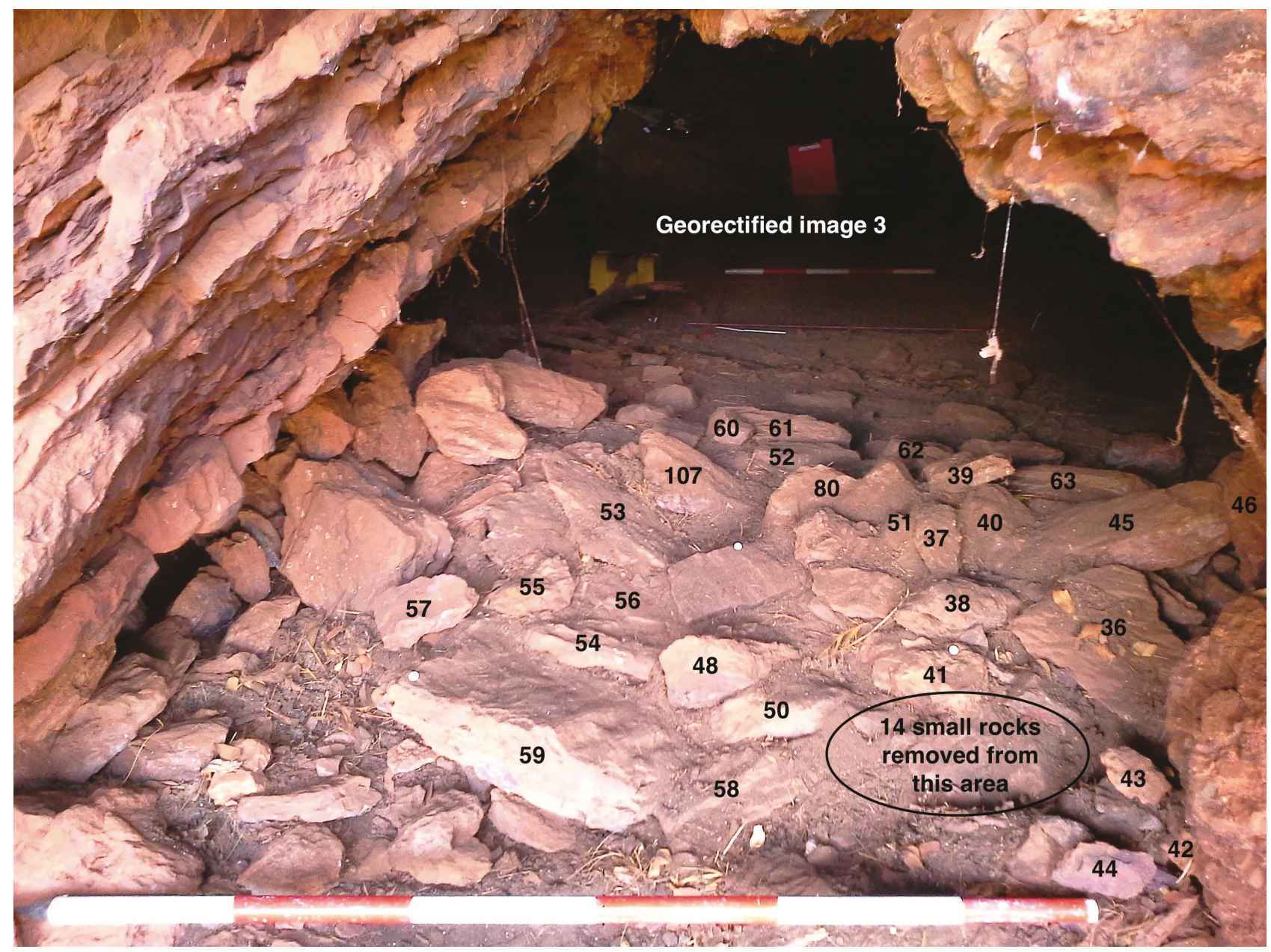

FIGURE 9 The built structure at PIL_5841 at the mid-way through dismantling when the wall had been reduced to the level of the interior floor height. Increments on the ranging pole are $20 \mathrm{~cm}$

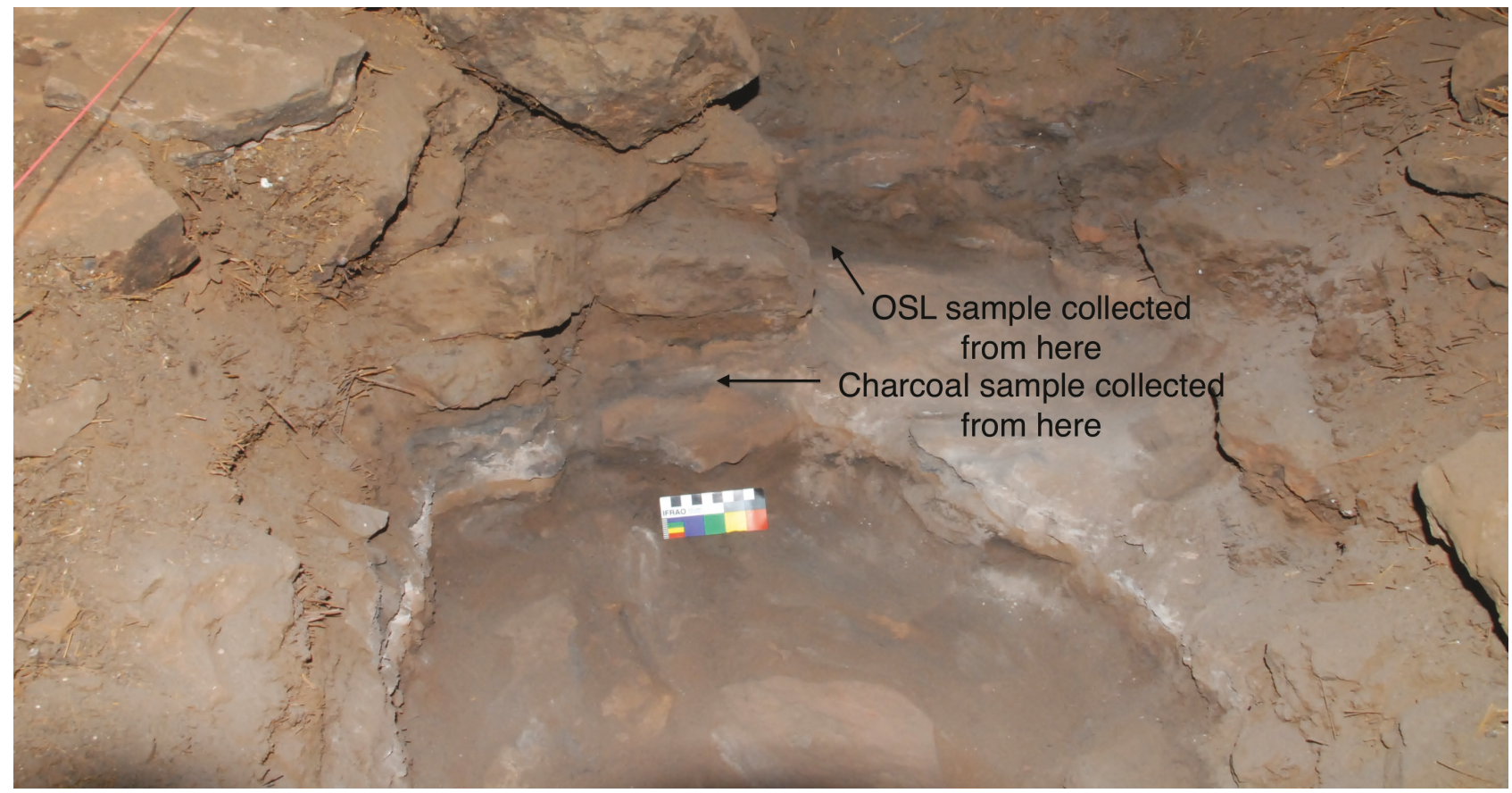


accumulated naturally as either (1) material has moved downslope from the outer chamber and built-up in and against the walled structure, and/or (2) small mammals have nested amongst the many crevices formed by the stones comprising the wall. As dismantling of the structure proceeded and rocks from below the level of the modern ground surface were removed, the faecal pellets, spinifex, charcoal and seeds continued, but were situated within a loose silt-rich deposit that had accumulated between the voids.

It was determined that this built structure was underlain by thick ash deposits that appeared to be cultural (though only one stone artefact was associated with these deposits), rather than sitting atop bedrock or roof-fall. A schematic representation of the north section of the deconstructed wall (i.e. that shown in Figure 10) is presented in Figure 11.

Two samples from the PIL_5841 built structure were submitted to the ANU Radiocarbon Dating Laboratory (Fallon et al. 2010):

- One wood sample from one of the logs originally positioned atop the structure (ANU-39037); and,

- An ash sample from a lens underlying, but seemingly not associated with, the structure (ANU-39025).

A further two charcoal samples from the test-pit (Square A) excavated in the outer chamber of PIL_5841, one from XU6 (ANU-39026) and the other from XU12 (ANU-39027), were also dated. Further information about the excavation is available in Wallis (2015).

Radiocarbon dating results are shown in Table 3. The wooden log sample returned a modern age estimate (ANU-39037). The sample from the ash lens underlying the rocks in the walled structure returned an age estimate of $13,980 \pm 80 \mathrm{bp}$, which calibrates to 17,193-16,568 cal. BP. The Square A samples returned uncalibrated age estimates of $3925 \pm 40$ bp (XU6), and $10,765 \pm 45$ bp (XU12). At the $95.4 \%$ confidence interval, these calibrate to $4422-4156$ cal. BP and $12,734-12,565$ cal. BP, respectively.

One OSL sample was also collected from underneath the PIL_5841 built structure and above the ash lens. As shown in Table 4, this produced an age estimate of $600 \pm 300$ years. Another OSL sample was collected from the north wall of the test pit in PIL_5841 at a depth of 55 cm below surface, just below the XU12 charcoal sample, producing an age estimate of $16,600 \pm 3600$ years.

The extremely low density of stone artefacts and the limited nature of the faunal assemblage from the Square A excavation (see Wallis 2015), coupled with the absence of grinding material and a lack of surface charcoal or hearths, though abundant charcoal at depth, suggest that PIL_5841 was used for non-secular purposes. Burnt

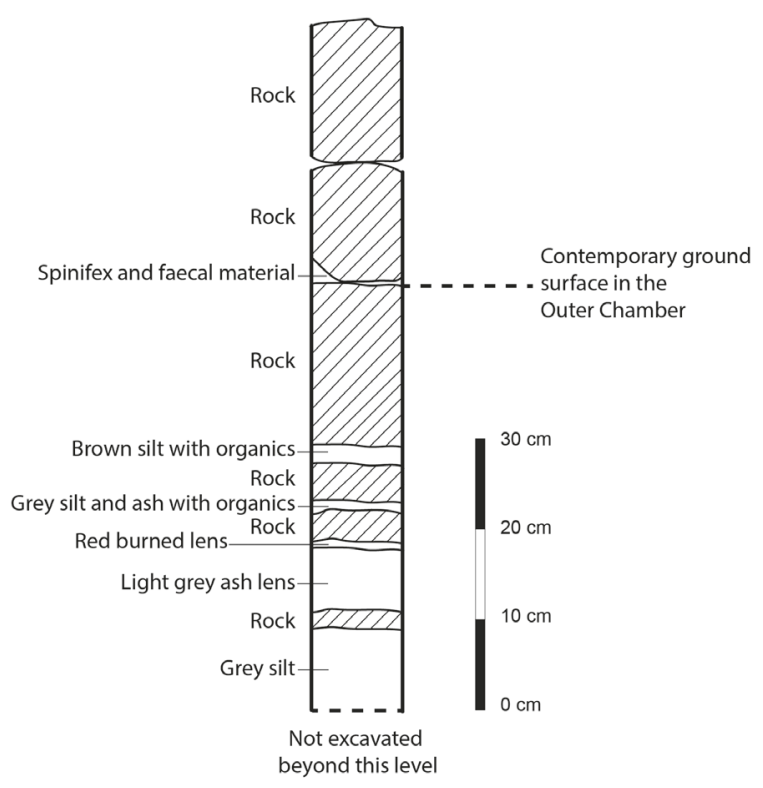

FIGURE 11 Schematic representation of the exposed north section through the centre of the deconstructed built structure in PIL_5841. The radiocarbon and OSL samples were taken from the 'Light grey ash lens' unit; the OSL sample was taken above the radiocarbon sample.

wood fragments scattered across the inner, middle and outer chamber of PIL 5841 were likely cultural and were probably used for the production of light, rather than being natural or remnants from a hearth.

The construction of the rock wall, topped by wooden branches, across one entrance had the effect of partially restricting access to the rockshelter's interior (though this was still easily available via the still open adjacent entrance). It may have served in some manner to protect the interior of the shelter from wind; however, given the small size and deep nature of the entrances it seems unlikely that even without the structure wind would be a major factor, regardless of the direction from which it was blowing. During the periods of fieldwork at the site there was no noticeable change in the impact of wind inside the rockshelter after dismantling the wall. Whether inadvertently, or by conscious design, construction of the wall also reduced the amount of sunlight entering the shelter, thereby making the interior chamber substantially darker than it would otherwise have been ${ }^{8}$; however, even with the entrance fully open, the inner and middle two chambers would have remained effectively lightless unless some source of illumination was introduced.

\footnotetext{
${ }^{8}$ Prior to dismantling of the structure it was extremely dark in the outer chamber of PIL_5841; however, as dismantling progressed, more and more light was admitted and it became very apparent just how effectively the structure had blocked light from entering.
} 
TABLE 3 Summary information about radiocarbon determinations from PIL_5841 and PIL_6000.

$\left.\begin{array}{llllllll}\text { Lab No. } & \text { Site } & \text { Sample Description } & \delta^{13} \text { C } & \begin{array}{l}\text { \% Modern } \\ \text { Carbon (pMC) }\end{array} & \text { D14C } & { }^{14} \text { C age } & \begin{array}{l}\text { Calibrated Age } \\ \text { cal. BP (probability) }\end{array} \\ \hline 39025 & \text { PIL_5841 } & \text { Ash lens } & -22 \pm 1 & 17.55 \pm 0.15 & -824.5 \pm 1.5 & 13,980 \pm 80 & 17,193-16,568(95.4 \%) \\ 39026 & \text { PIL_5841 } & \text { Sq. A XU6 } & -25 \pm 1 & 61.34 \pm 0.30 & -386.6 \pm 3.0 & 3925 \pm 40 & 4422-4219(85.8 \%) \\ & & & & & & & 4208-4156(9.6 \%)\end{array}\right)$

As discussed earlier, Haast (n.d.: 19) suggested that the use of wood in built structures potentially indicated a desire by builders to allow access to areas behind the structure or facilitated their easy deconstruction. This seems unlikely in the case of PIL 5841 for several reasons. Firstly, removal of the wood atop the built structure did not allow for easy access to the shelter via this entrance, as the gap between the top of the structure and the entrance ceiling was quite small. Further, the other entrance to the site afforded much easier access, even when the wood was removed. The presence of this southern entrance led Czerwinski (2013) to discount the PIL 5841 built structure as having served as a cache, which seems logical.

During fieldwork, following similar discussions held between BHPBIO staff members Allan Ewen and Mike Marsh, Banjima representative Garren Smith offered his views on the purpose of the built structure based on the physical evidence and his knowledge of traditional cultural practices. Garren suggested that the opening may have been sealed to improve the chances of hunting success during periods of ceremonial activity, when larger numbers of people may have needed to be fed. By blocking the northern entrance to the site, macropod access to the site was restricted to the southern entrance. $\mathrm{He}$ posited that some men participating in ceremonies in the local area, probably the previous years' initiates, would have been required to provide food for the current year's participants. Rather than 'aimlessly' hunting, they would likely have targeted locations that macropods were known to inhabit, such as the PIL_5841 rockshelter. Lighting fires, either inside or outside the shelter, or a person entering the site with a lit branch, would have had the effect of causing panic amongst any macropods inside and, with only one means of exit, they would have been an easy target for waiting hunters.

This hypothesis fits well in some respects, though not others, with the animal habitat theory posited by Bindon and Lofgren (1982). There is evidence that small animals used the spaces between the rocks of the PIL_5841 built structure for nesting, based on the abundance of loose organic materials present. However, the addition of the wood atop the structure did not provide a suitable habitat for nesting animals or allow escape that was not already available via the other entrance. Thus, it seems unlikely that the wall was constructed for the purpose of serving as an animal habitat per se.

It is possible that the relatively elevated height of the southern entrance may have made it easier to hunt from that position, especially after the lower, northern entrance was sealed. However, given the close proximity of both entrances to each other and their sizes, it is not really clear whether a substantial advantage was gained by blocking the northern entrance. On the weight of the available evidence it seems that blocking ingress or egress for prey species to facilitate hunting success is a possible function for the built structure blocking the northern entrance of PIL_5841, though it does not provide a fully satisfactory explanation.

In summary, the radiocarbon dating of the ash lens beneath the walled structure and from the excavation within the outer chamber of the site indicates initial use of PIL_5841 around 17,000 cal. BP, immediately after the peak of the LGM. It seems that site use was reasonably sporadic until about $4300 \mathrm{cal}$. BP, when there was a peak in both charcoal and stone artefacts (though the latter are still found in low density) (Wallis 2015). The abundant charcoal clearly demonstrated fires being lit in the shelter at this time, though the purpose was unlikely to be for warmth given the normally high temperatures experienced inside the rockshelter even during bitterly cold winter days, or for cooking animal foodstuffs, given the limited nature of the faunal assemblage recovered. Sometime thereafter, possibly around 400-500 years ago, both charcoal and stone artefacts became extremely rare in the outer chamber, suggesting another change in how people were using the site. These patterns fit well with the broader patterns 


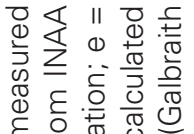

0
0

0 .

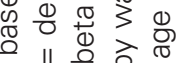

जo ठ ठ ह

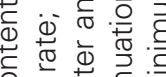

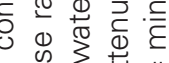

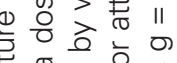

雪

ह 음

ब.

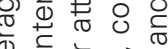

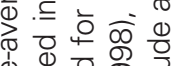

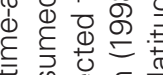

可

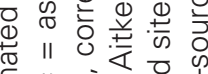

है 0 के

可

॥

○ $\overline{0}$

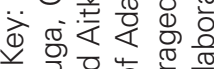

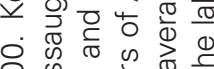

8000

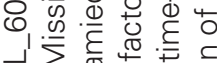

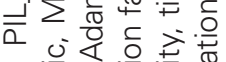

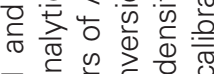

于文产完芒

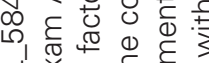

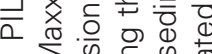

$\varepsilon \sum \frac{\omega}{\omega} \frac{c}{\omega}$

至

을

둥 잉

.

$\Phi$ 용

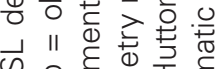

○응 ह

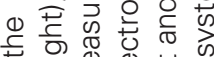

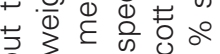

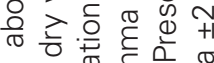

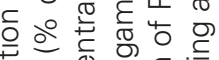

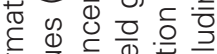

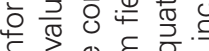

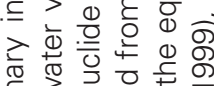

है

\begin{tabular}{|c|c|c|c|}
\hline 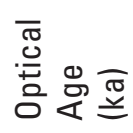 & $\begin{array}{l}n \\
0 \\
0 \\
0 \\
0 \\
0\end{array}$ & 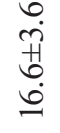 & $\begin{array}{l}0 \\
0 \\
\text { in } \\
\text { ñ }\end{array}$ \\
\hline 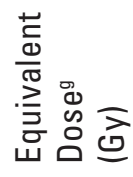 & $\begin{array}{l}n \\
0 \\
0 \\
0 \\
0\end{array}$ & 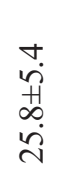 & $\begin{array}{l}0 \\
\dot{0} \\
\dot{H} \\
\dot{0}\end{array}$ \\
\hline 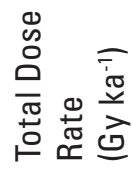 & 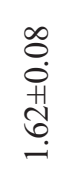 & $\begin{array}{l}\infty \\
0 \\
0 \\
+1 \\
0 \\
\stackrel{0}{0}\end{array}$ & $\begin{array}{l}0 \\
0 \\
0 \\
0 \\
0\end{array}$ \\
\hline
\end{tabular}

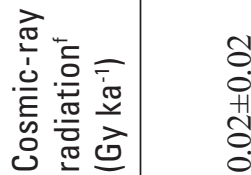

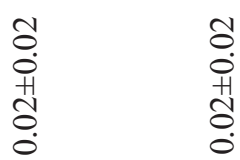

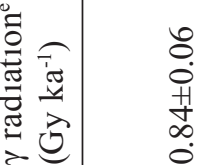

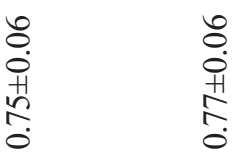

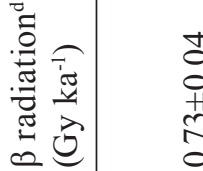

$\begin{array}{ll}0 & 0 \\ 0 & 0 \\ 0 & 0 \\ 0 & \text { H } \\ 0 & 0 \\ 0 & 0\end{array}$

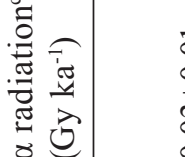

-
0
0
0
0
0

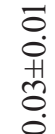

is

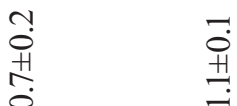

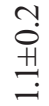

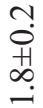

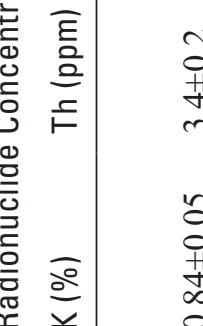

$m$
0
0
0
1

$n$
0
$n$
$n$

ㅎ.

$\begin{array}{ll}n & + \\ 0 & 0 \\ 0 & 0 \\ +1 & 0 \\ 0 & 0 \\ 0 & 0\end{array}$

ํ.

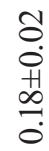

a

몸

荘

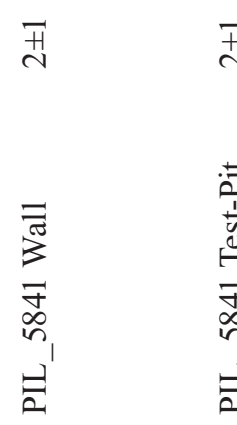

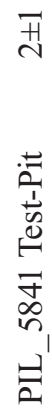

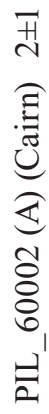

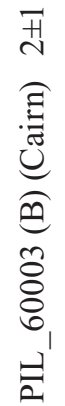


TABLE 5 Summary data for the rocks comprising the walled structure in PIL_6000. Note that three of the rocks were left in situ (either to facilitate OSL dating or because they were too large to safely move) and thus aren't included in weight values.

\begin{tabular}{llccccc} 
Measurement & Number of Rocks & Mean & Maximum & Minimum & Mode & Median \\
\hline Length (mm) & 97 & 276 & 990 & 80 & 410 & 250 \\
Width (mm) & 97 & 166 & 360 & 65 & 210 & 150 \\
Thickness (mm) & 97 & 79 & 230 & 20 & 50 & 70 \\
Weight $(\mathrm{kg})$ & 94 & 6 & 55 & 0.2 & 1 & 4 \\
\hline
\end{tabular}

of occupation for the Packsaddle Range, which suggest that there was a regional population on the Hamersley Plateau since the Pleistocene but there may not have been a permanent population in the Packsaddle Range itself until the mid-Holocene (e.g. Comtesse and Harris 2008; Dias et al. 2011; HEH 2012a, 2012b, 2013; Law et al. 2010; Marwick 2002a, 2002b, 2005; Maynard 1980; Morse 2009; Slack 2014; Slack et al. 2009; Veitch et al 2005; Veth 1995, 2000; Wallis and Matthews 2015).

Based on the available OSL chronology, in the last millennium the built structure was constructed across the northern opening of the rockshelter, thereby restricting easy entrance to the cave's interior (and coinciding with a decline in charcoal in the deposits of the outer chamber). Thereafter, the built structure formed a sediment trap, with material being trapped and building up inside the shelter against the structure. The modern radiocarbon determination on the wood used to block the opening at the top of the built structure indicates that the latter, at least, was being maintained in the recent past and supports the OSL indication of it having been constructed in the last millennium. It is also likely that many of the burnt pieces of wood on the floor of PIL_5841 attest to the use of the site within the last few hundred years.

The presence of hollowed out limonite deposits in the outer chamber of PIL_5841 suggest the site may have been a pigment source. This leads to the possibility, though largely untestable, that the built structure was erected in order to indicate to people the restricted nature of access to the site without needing to seal both entrances.

While the dismantling of the built structure at PIL_5841 successfully provided information about its method of construction and antiquity, it unfortunately did not provide conclusive evidence as to the function of the structure. This was not the case for the built structure at the PIL_6000 site, where function was very clear.

\section{PIL_6000}

Ninety-seven rocks were removed from the built structure in PIL_6000 (Table 5). In addition, numerous smaller rocks were removed, particularly along the structure's western margin (i.e. that closest to the shelter wall), these were not individually weighed or measured as they were not convincingly part of the structure. All rocks in the structure were local BIF and none showed any signs of cultural modification. The largest rock in the structure measured c. $1 \mathrm{~m}$ in maximum dimension; owing to its large size it could not be safely moved and therefore it was not weighed. The heaviest rock that could be moved weighed $55 \mathrm{~kg}$. As summarised in Table 5 , the average rock measured $276 \times 166 \times 79 \mathrm{~mm}$ and weighed $6 \mathrm{~kg}$; the most common rock mass was $1 \mathrm{~kg}$.

Unlike the lower courses of the built structure in PIL_5841, there was very little extraneous material between the rocks forming the PIL_6000 walled structure. During dismantling, a cavity was revealed in the structure, divided into two chambers by a piece of BIF too large to be moved safely (Figures 12a and 12b). Sediment within the chambers was examined and it was apparent that no surviving cultural material was cached within it.

Deconstruction revealed the PIL_6000 built structure was circular to ovoid in plan, separated into two distinct hemispherical chambers by a large rock lying across the approximate centre of the structure (Figure 12b). The modal rock size suggests there was a definite preference among the builders for rocks that could be easily moved by one person, sourced from the abundant roof-fall available elsewhere. The range of rocks used fall into a fairly constrained set of physical criteria in terms of size and weight, which is typically expected to be the case with a humanly constructed, rather than naturally occurring, feature.

The heaviest and largest rocks in the structure were positioned at its base, including the substantial rock that served to separate the structure into two chambers. Those rocks used for the upper courses were typically more restricted in weight and size and easy to manoeuvre into place by a single person; they also tended to be lighter and flatter than those lower in the structure. This pattern fits with engineering requirements for a structure designed to form a 'wall' around an open interior space, rather than one in which the desired outcome was a solid structure. 
During dismantling, two small pieces of wood were recovered from the structure. The first of these comprised a c. $25 \mathrm{~cm}$ piece from atop a rock at the top of the western 'wall' of the structure. It was seen prior to the removal of any rocks, and was not 'wedged' in place, but easily removed without the need to move any of the overlying stones. Czerwinski (2013: 46) had hypothesised that this wood was used 'to ensure whatever was placed within the wall did not get crushed by the weight of the rocks'. This piece of wood did not appear to be culturally modified in any way, and was too small to have supported any of the rocks above it; it was thus assessed as being non-structural.

A second piece of wood was recovered from towards the base of the western ('rear') wall of the south-west chamber. This piece measured approximately $24 \mathrm{x} 4 \mathrm{~cm}$ (and thus again was not large enough to have served a structural purpose), and did not appear to have been culturally modified. Nevertheless, in comparison to the first piece of wood, this piece appeared to be more convincingly in situ: it was not observed until many rocks overlying it had been removed, was firmly wedged between rocks and thus could not have accidentally 'fallen in' recently.

The lower of these two pieces of wood was submitted for radiocarbon dating. As shown in Table 3, it returned an uncalibrated age estimate of $1210 \pm 40 \mathrm{bp}$, calibrated to $1182-963 \mathrm{cal}$. BP. The implications of this date are somewhat unclear, as the wood appeared not to have been deliberately cached within the structure, nor did it appear to have had a structural purpose. While it provides a maximum age for the built structure, it is possible that the structure is younger than this (see below).
Two OSL age determinations were obtained on sediment underlying rocks in the lowest course of the PIL_6000 built structure (Figure 12b). Sample A, collected from under a rock along the far western margin of the structure, returned an age estimate of 5200 years, while Sample B, collected from under the large rock dividing the structure into its two component parts, produced an age estimate of c. 400 years (Table 4). This discrepancy requires some discussion.

Given OSL Sample A's position against the rockshelter wall, where the roof is very low, the strong possibility exists that this rock, although used as part of the lowest course of the structure, may originally have been part of natural roof-fall (which is abundant along all of the PIL_6000 back wall). It may therefore have fallen from the roof around 5000 years ago, and sometime after that event people built the structure above it, taking advantage of its position.

OSL Sample B, collected from under the central rock in the built structure, is much younger than OSL Sample A, dating to within the middle of the last millennium. The radiocarbon age of the wood that was wedged in between rocks along the western margin of the cairn (a few courses of rock above where OSL Sample A was collected) was different again at 1070 years old (i.e. the mid-point of the calibrated age range).

Considered collectively, the younger OSL date of c. 400 years is more likely to be the true age of the feature's construction. If the structure was built c. 5000 years ago, it is unlikely that a piece of wood only 1070 years old could have been incorporated into its lower courses, unless the structure was substantially
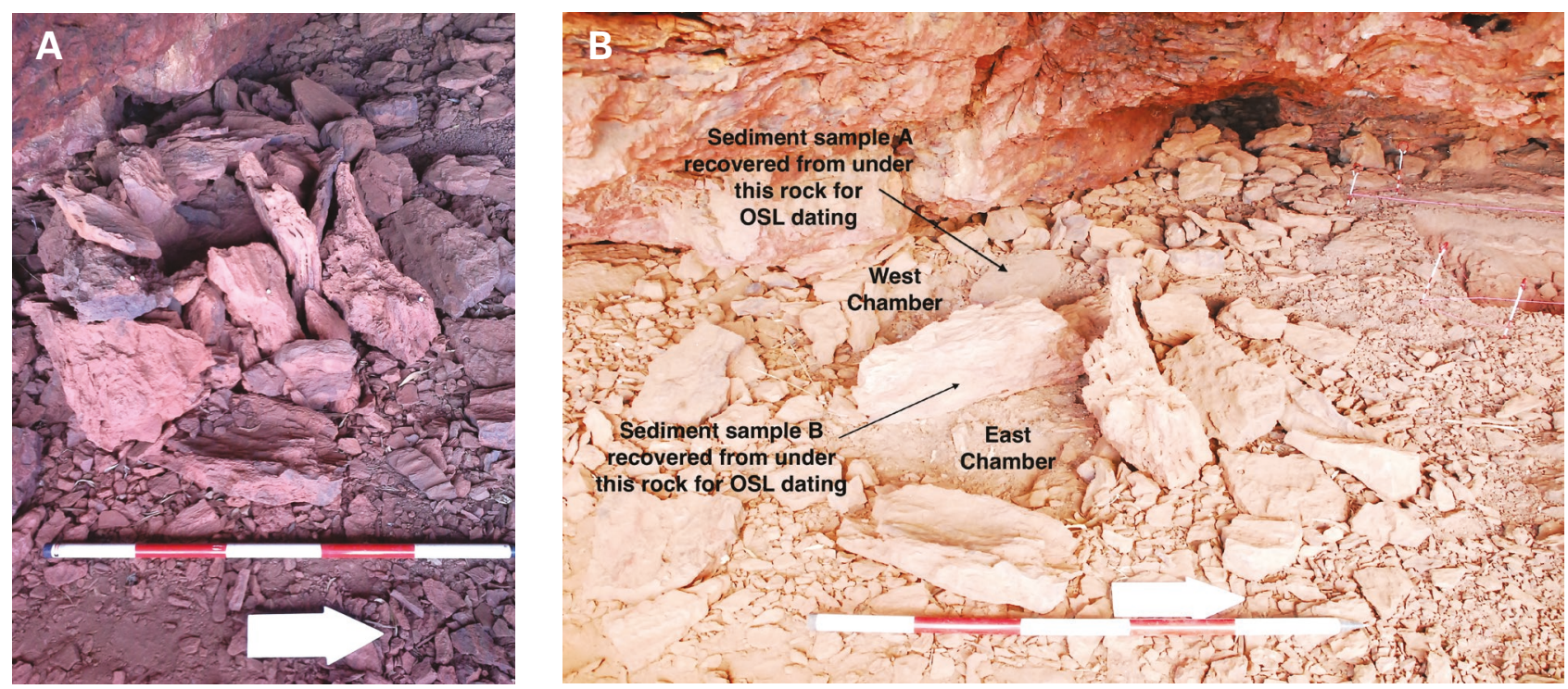

FIGURE 12 A) View of the PIL_6000 built structure partway through deconstruction, where the uppermost stones have been removed and the central cavities are visible in the centre of the structure. Increments on the ranging pole are $20 \mathrm{~cm}$. B) View of the PIL_6000 built structure nearing the completion of deconstruction, showing the two internal chambers and the locations of the OSL sediment samples. Increments on the ranging pole are $20 \mathrm{~cm}$ and the arrow indicates north. 
rebuilt around that time. While this is possible, it seems unlikely. Similarly, if the structure was built 5000 years ago, it is difficult to see how an age of c. 400 years could be obtained from under the central rock, unless the structure was substantially rebuilt at that time, or the central rock was moved. Again, the former seems unlikely and, given the central rock's core position at the base of the structure and its large size, it is unlikely to have been moved after originally being positioned. The inclusion of window stones to allow access to such structures means it is unlikely cairns would need to be dismantled and/or rebuilt to enable access to their interior. Given its apparent non-cultural and nonstructural status, the 1,070 year old piece of wood is possibly part of a natural accumulation at the back of the shelter from trees growing at the front of the shelter.

Based on the nature of the built structure and rockshelter, it seems most parsimonious to suggest that people took advantage of the presence of existing roof-fall at the back of the rockshelter when building the structure. A piece of wood amongst the roof-fall at the back of the rockshelter was then inadvertently incorporated into the lower courses of the western margin of the structure, which was built atop the naturally accumulated roof-fall. The OSL age determination of c. 400 years obtained from under the large rock in the centre of the cairn is thus considered most likely to represent the true age of construction for the cairn.

The presence of the internal chambers confirms the interpretation of the PIL_6000 structure as a cache, in line with the initial assessment by Czerwinski (2013). There are two possible reasons for the absence of any cultural material within the structure:

- The chamber(s) had been deliberately emptied; or,

- Organic material had been present but deleterious preservation conditions caused such material to decay, leaving none remaining at the time of the 2014 investigation.

There is no evidence to preferentially support either of these hypotheses.

The difficult nature of access to PIL_6000, low ceiling height of the shelter and rock strewn floor means the site is not well-suited for use as a living area. While it could be used for shelter in an emergency, there are many other more suitable shelters in the immediate vicinity. Owing to the presence of large pieces of roof-fall on the talus slope in front of the structure it cannot easily be seen from above, below or adjacent to the rockshelter until one is extremely close. The rockshelter is quite difficult to access from the gully below; however, it is relatively easy to access from above if its location is known. It seems possible that the structure in PIL_6000 was built to protect sacred rather than secular material. This would be consistent with ethnographic and ethnohistorical information from the Pilbara and Western Desert about such structures and ceremonial paraphernalia having restricted audiences.

\section{ATYPOLOGY OF BUILT STRUCTURES IN ROCKSHELTERS}

Unfortunately, as has been alluded to above, to date the conflation of different forms of built structures in Pilbara rockshelters into a single site type has served to disguise the variation between them. This tendency also makes it difficult to examine potential or actual variation in the distribution of different types of built structures and to address issues of function - clearly they were not all constructed to serve a single purpose. To address such issues, a consistent typology for recording such features is required. The following typology is based on morphological grounds and, as far as we can determine through a review of all available reports of such structures, encapsulates all known examples of built structures that occur within rockshelters thus far recorded.

Type 1: 'Walls' that totally or partially seal off rockshelters, crevices or niches, with the area that is sealed off being unsuited for use as a living area for people owing to its low ceiling height (usually less than $0.5 \mathrm{~m}$ ) and/or small size. Typically these are linear, one course wide and may vary in length from $0.5-12 \mathrm{~m}$. They may or may not incorporate branches or hollowed limbs and trunks as structural components. The built structure shown in Figure 13 is an excellent example of a Type 1 wall, with the area behind the wall being approximately $60 \mathrm{~m}^{2}$, but with an average ceiling height of just $40 \mathrm{~cm}$, making it unsuitable for human occupation.

Type 2: 'Walls' that either (a) totally or partially prevent access to otherwise potentially habitable (i.e. those with a reasonable ceiling height and size) rockshelters (or parts of rockshelters) or (b) don't prevent access to a potentially habitable rockshelter because of the presence of other entrances. Again, these walls can vary in length, but tend to be linear and only one course wide. They may or may not incorporate branches as structural components. The structure in PIL_5841 is a good example of a Type 2a built structure (Figure 5).

Type 3: Freestanding structures ('rock piles') of an approximately circular or ovoid shape, usually up to $1 \mathrm{~m}$ in maximum dimension that contain a central chamber or cavity that can be accessed by the removal of a 'window' stone. Partial collapse or dismantling may have restricted the identification of the window stone. These structures typically do not incorporate branches as structural components. The structures in PIL 6000 and PIL_2258 are good examples of Type 3 built structures (Figures 2 and 7).

Type 4: Freestanding structures ('rock piles') without any central chamber or cavity of a maximum dimension of up to $3 \mathrm{~m}$ in length or width, and up to $1 \mathrm{~m}$ in height. Their shape may be variable, but generally they tend to be circular to ovoid in plan view. Those that do not incorporate branches as structural components comprise Type 4a (Figures 3 and 14), while those that incorporate an upright branch positioned approximately centrally 
within the structure comprising Type $4 \mathrm{~b}$ (Figure 15). Type $4 \mathrm{~b}$ structures are generally smaller than Type $4 \mathrm{a}$ structures.

These categories do not always fit neatly with different functions, though some generalisations can be made, along with some suggestions about how to test which idea of function might be appropriate.

Some instances of Type 1 built structures might have served as caches, either to protect objects or to conceal them from view, the best evidence of which would be the presence of artefacts behind such a structure. However, it should be noted that the absence of artefacts behind such a structure should not be taken for proof that they did not have a caching function, since such artefacts may have deteriorated or been deliberately removed prior to the structure being recorded. When such structures seal small niches within rockshelters that otherwise contain no evidence for secular use, and/or seal entire rockshelters that were so small as to be unsuited for use as human shelter it is possible that the cached material may have been of a sacred or restricted nature. Another potential function of Type 1 structures is that they were built to prevent animals from retreating into difficult to access, low ceilinged niches while being hunted (though if they did retreat into such spaces they could be smoked out; see Brehaut and Vitenbergs 2001: 18). In cases where the rockshelter also contains evidence of habitation, it is possible these structures may have been built to prevent crawling infants from entering them. As Bindon and Lofgren (1982) originally suggested, some of these structures may have served as animal habitats. A further option for the purpose of these structures was spiritual, in that it is possible they could have been used to 'confine' Ancestral Beings or 'spirits'.

Type 2 built structures may have functioned to indicate a rockshelter was restricted to particular groups of people, or to conceal something large that may have required manoeuvrability to position it, such as a burial. In the first instance, the artefactual assemblage might be quite different to what would occur in an open site used by all. In the second instance, the presence of skeletal remains within the rockshelter would provide evidence of that function. Another explanation for these structures might be that they were simply byproducts of floor clearing exercises, in which case the rockshelter floors could be expected to be largely free of such debris. Banjima representative Yuddy Butler (pers. comm. to LW Sept 2015) also suggested that in some instances these built structures may have provided protection from extreme weather events such as cyclones, or as windbreaks for use during less severe but generally inclement weather. Assessing the relationship between structures, rockshelter aspect, prevailing wind directions and the presence of grinding materials or general occupation debris would be useful for assessing whether they were possibly constructed to provide sheltered areas for women to use when winnowing seeds from chaff prior to grinding during windy weather (cf. Palmer 1978: 36).

Almost without exception, Type 3 built structures likely functioned as cairns or repositories, including potentially as secondary interment sites. The presence of the central chamber, and potential a window stone, provide clear support for such an interpretation, even in the absence of any material culture or skeletal material within them. Such structures themselves are not ceremonial or spiritual per se, as they served the secular function of protection, though they might well have cached ceremonial or spiritually important objects. It may also be of relevance in such instances to consider how easily accessible and/or visible from afar that Type 3 built structures are. If indeed the purpose of some of these structures was to secrete sacred objects, we might expect them to be located in rugged gullies that are not easily accessed or, alternatively, in locales where they cannot easily be seen.

Type 4 built structures are perhaps the most variable in terms of potential functions. Type 4 a structures may variously have functioned as steps (in which case their position within the rockshelter should be such as to provide access to a high part of the site), secondary burial chambers (in which skeletal remains might be present), been the remnants from a floor clearing exercise for the purposes of improving the comfort level of a habitable shelter (in which case the floor should be clear of such debris), or simply be what remains after a Type 1 walled cavity was dismantled (in which case there should be a niche present; note that Type 3 structures did not require dismantling to access due to their particular design which allowed easy access through removal of a single stone). Larger examples of Type 4a built structures may have also served as primary burial sites, to protect the deceased from predators in a region where interment in the ground was difficult. Type $4 \mathrm{~b}$ built structures (i.e. those similar to Type 4a structures but incorporating a central branch) may have served either as ladders to provide access to high ledges (in which case their positioning within the shelter is key to document) or, if they had once had other organic material leaning against the main branch, may have served as protective windbreaks (and again their position within the rockshelter is important in determining this, along with knowledge of prevailing wind directions).

Distinguishing between these potential functions requires careful consideration of the local context, association with other cultural materials, assessment of the size, structure and positioning of the structure and an investigation of whether skeletal materials are preserved. In many instances, it may be possible to exclude certain possible functions, but not to settle on a single definitive interpretation. Further, some suggested functions are incompatible with other uses while others are not. And, of course, it remains possible that there are alternative functional explanations not covered above. 


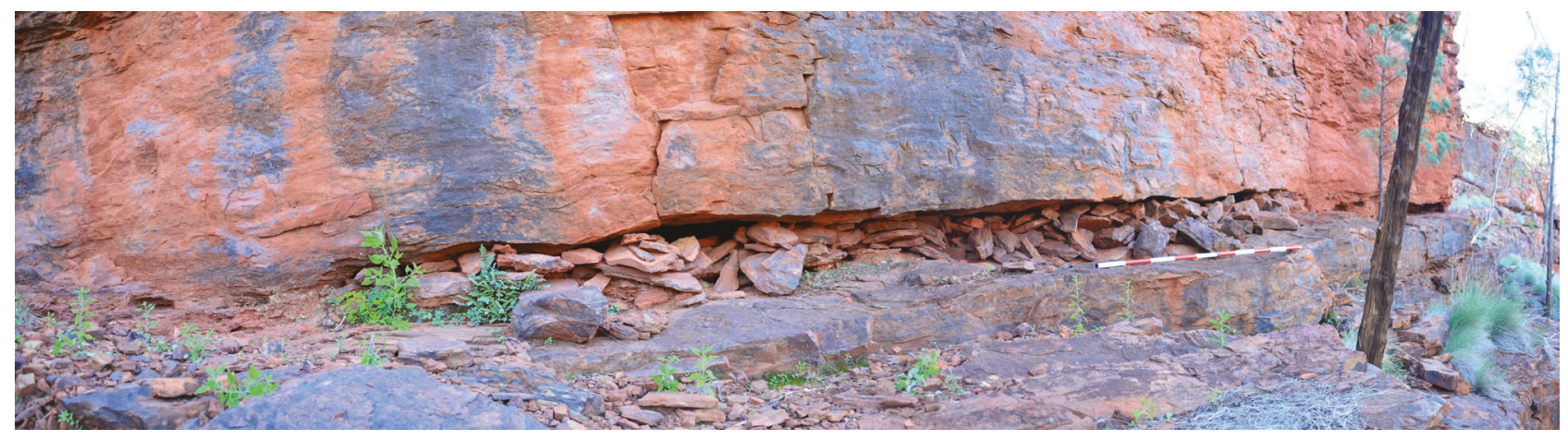

FIGURE 13

View of an extensive built structure sealing a low ceilinged niche unsuited to habitation. The increments on the ranging pole are $20 \mathrm{~cm}$.

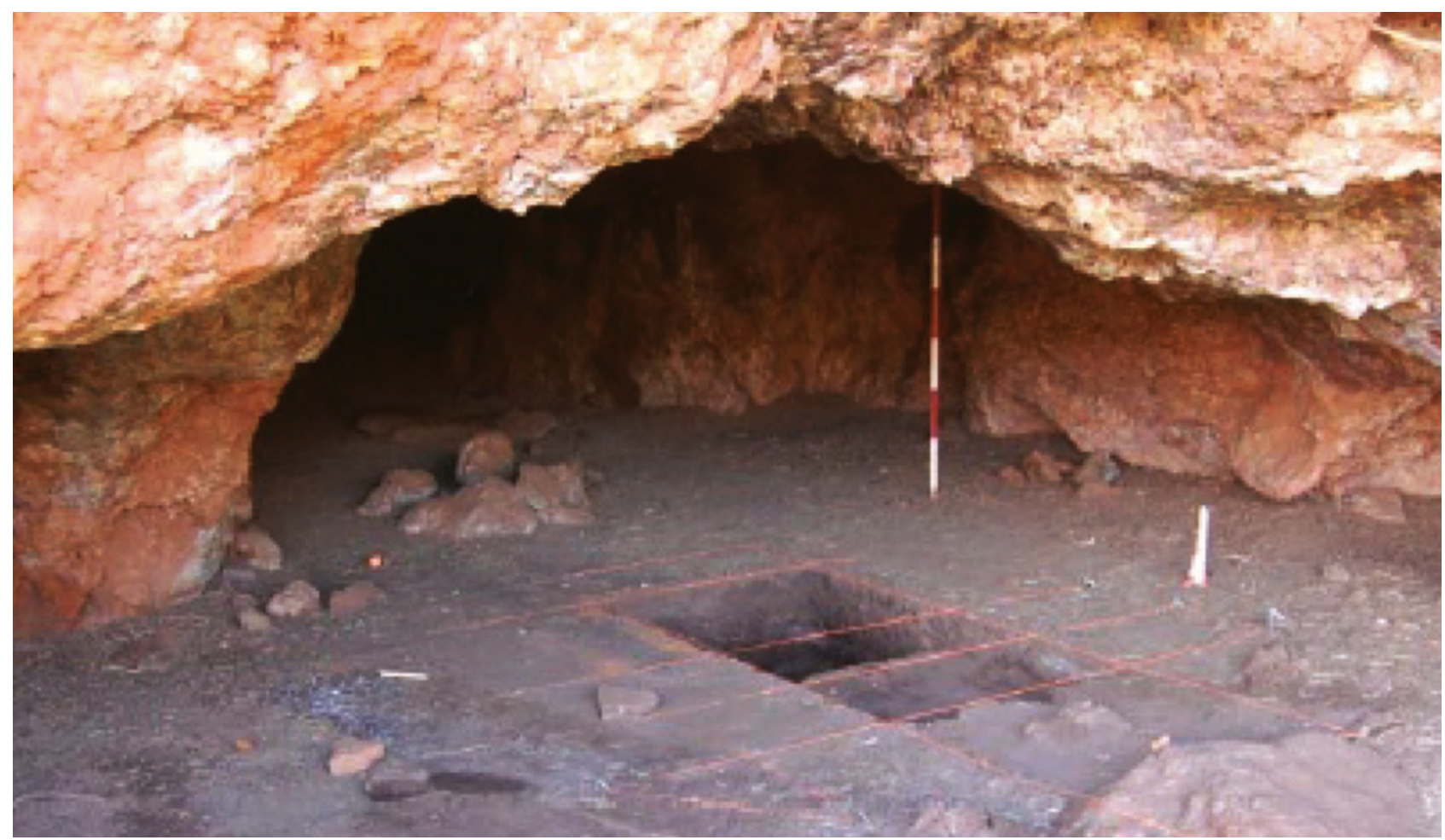

FIGURE $14 \quad$ View of a built structure of Type 4a. The increments on the scale are $20 \mathrm{~cm}$ (photo from HEH 2013).
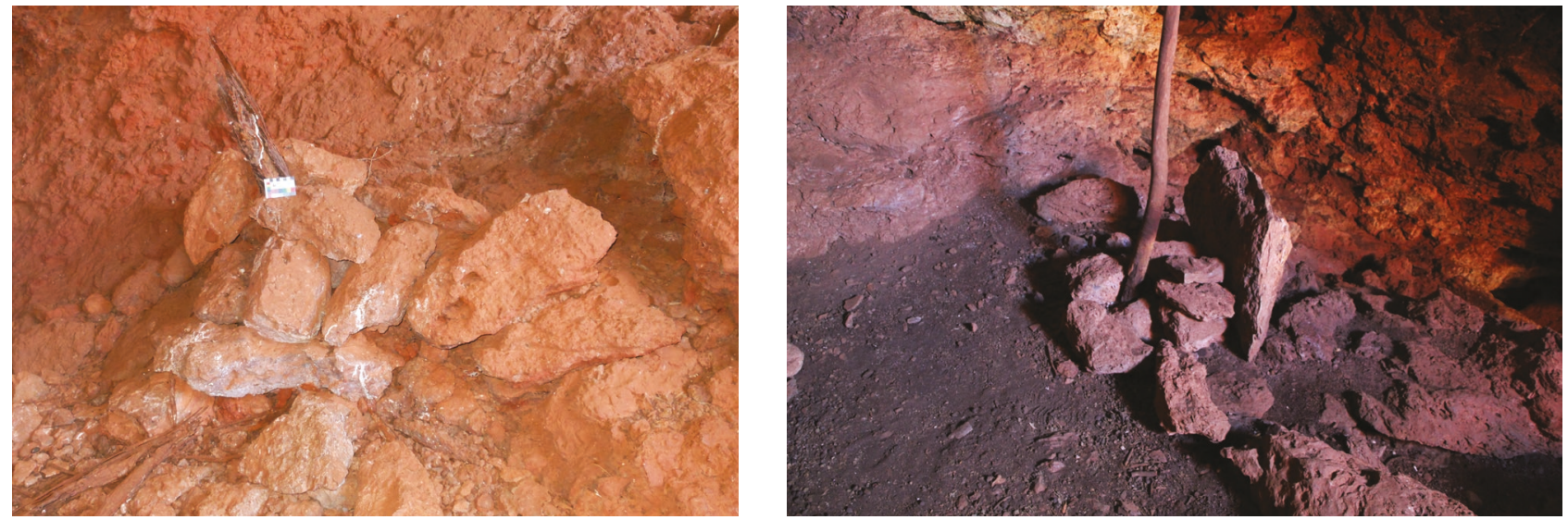

FIGURE 15

View of built structures of Type $4 \mathrm{~b}$. In the image on the left the increments on the scale are $1 \mathrm{~cm}$, with the whole scale measuring $8 \mathrm{~cm}$ in length. 


\section{CONCLUSION}

Built structures of various forms are relatively common in rockshelters of the Hamersley Plateau, particularly the Packsaddle Range. There appears to be no single or simple answer as to why these structures were built, however, their individual context and morphologies are extremely important in distinguishing between them. Likely functions included caches, burial chambers, safety precautions (against both tangible and intangible threats), steps, ladders, water barriers and windbreaks, intangible spiritual 'barricades', to aid hunters by isolating animals more effectively or to prevent prey escaping into unreachable locales, and, as originally suggested by Bindon and Lofgren (1982), in some instances they may have served as enhanced animal habitats.

There is sound direct evidence in just a few instances, and growing indirect evidence in many other instances, that these structures are indeed a late Holocene development, as originally posited by Brown (1987).

Unfortunately to date, limited attention has been paid to these structures and information that might help to ascertain their function (such as ceiling height above the structure) is often lacking (Westell and Wood 2014). Furthermore, the structures are often misidentified and categorised unsystematically under a range of highly variable terms. It is strongly recommended that future studies adopt, and where necessary, modify, the morphological typology that has been proposed in this paper. It is hoped that greater consideration and reporting of findings about built structures in rockshelters, and more nuanced recording of their range and variations, will assist in developing better understandings of their role(s) and meaning(s). Until a greater level of fundamental data about built structures is available and accessible in published contexts, it is extremely difficult to adequately assess their significance in a management context.

\section{ACKNOWLEDGEMENTS}

We offer our thanks and acknowledgement to Banjima people, including Elders past and present, with whom the authors have worked directly and who have granted their permission and support for the material to be published. We also thank other Aboriginal groups of the Pilbara who have worked with other consultants recording these sites. Thanks to BHP Billiton Iron Ore for supporting and partially funding this project, in particular Annunziata (Nunzi) Strano and Jade Pervan. Matthew Cupper undertook the OSL dating of the two case study structures. Thanks to Ken Mulvaney and Ed Clarke from Rio Tinto for assistance in paper preparation, and to Kelsey Lowe, Jordan Ralph, Claire St George, Mick Macmahon, Allan Ewan, Paul Taylor, Pete Sweeney, Annunziata Strano, Mike Marsh, Yuddy Butler, Benson Donta, Dennis Long, Troy Long, David White, Thomas Robinson, Garren Smith, Preston Snook and Kyle Eaton for assistance during fieldwork. Thanks to Brendon Bobby of the Kuruma
Marthudunera Aboriginal Corporation for permission to cite information about Guruma traditional practices related to the drying of meat, and to Annie Ross, Louise Hitchcock, Robyn Stevens, Ed Clarke, Alex Walter, Mike Marsh, Fiona Hook, Ben Fordyce, Jillian Barteaux and others (whose identities we can't recall due to the overwhelming number of social interactions) who provided useful feedback at the Australian Archaeological Association conference in which an abbreviated version of this paper was presented. Our thanks for valuable feedback from Ken Mulvaney, Mike Marsh, Caroline Bird and an anonymous referee, whose comments greatly improved the clarity of this paper, as did the input from the Editor; any remaining errors remain our responsibility.

\section{REFERENCES}

Adamiec, G. and Aitken, M.J. (1998). Dose-rate conversion factors: update. Ancient TL 16: 37-50.

Berndt, R.M. (1974). Australian Aboriginal Religion. Iconography of Religions Series. EJ Brill: Leiden.

Bindon, P. and Lofgren, M. (1982). Walled rock shelters and a cached spear in the Pilbara region, Western Australia. Records of the Western Australian Museum 10: 111-126.

Brehaut, L. and Vitenbergs, A. (eds) (2001). The Gurama Story: Gurama-Yharntu Wangka. Jukurrpa Books: Alice Springs.

Bronk Ramsey, C. (2009). Bayesian analysis of radiocarbon dates. Radiocarbon 51: 337-360.

Brown, A.R. (1913). Three tribes of Western Australia. The Journal of the Royal Anthropological Institute of Great Britain and Ireland 43: 143-194.

Brown, S. (1987). Toward a Prehistory of the Hamersley Plateau, North-West Australia. Research School of Pacific Studies, The Australian National University: Canberra.

Brown, S. and Mulvaney, K. (1983). Test-Pit Excavations at Aboriginal Sites P4627, P4623, P5315 and P5316, PerthDarwin National Highway, Newman-Port Hedland Section. Unpublished report to the WA Main Roads Department.

Bunting, D. and Lantzke, D. (2007). A Report on the Recovery of Skeletal Remains Exposed During Routine Earthworks at Finucane Island, Port Hedland. Unpublished report to the Department of Aboriginal Affairs.

Clarke, C. and Smith, M. (1979). Aboriginal Sites of the Fortescue River in the Vicinity of the Mt Newman Mining Company Barrages. Unpublished report to the Mt Newman Mining Company.

Clement, E. and Schmeltz, J.D.E. (1903). Ethnographical notes of the Western Australian Aborigines with a descriptive catalogue of a collection of ethnographical objects from Western Australia. Internationales Archiv fur Ethnographie 16: $1-29$.

Comtesse, S. and Harris, J. (2008). Mining Area $C$ (C, E and F Deposit) Salvage Excavation Report. Unpublished report to BHP Billiton Iron Ore.

Czerwinski, P. (2013). Part C of the Detailed Site Recording of Rockshelters in BHPBIO Packsaddle 4, Mining Area C, Pilbara, WA. Unpublished report to BHP Billiton Iron Ore.

Davidson, D.S. (1952). Notes on the pictographs and petroglyphs of Western Australia and a discussion of their affinities with appearances elsewhere on the continent. Proceedings of the American Philosophical Society 96(1): 76-117. 
Dias, A., Hook, F. and Di Lello, A. (2011). Report of the Archaeological Excavation Programme of Seven Rock Shelter Sites within the Mining Area C Development and Railway, Packsaddle, Western Australia. Unpublished report to BHP Billiton Iron Ore.

Fallon, S.J., Fifield, L.K. and Chappell, J.M. (2010). The next chapter in radiocarbon dating at the Australian National University: status report on the single stage AMS. Nuclear Instruments and Methods in Physics Research B 268: 898-901.

Elkin, A.P. (1993). Aboriginal Men of High Degree: Initiation and Sorcery in the World's Oldest Tradition. Inner Traditions: Rochester, Vermont.

Galbraith, R.F., Roberts, R.G., Laslett, G.M., Yoshida, H. and Olley, J.M. (1999). Optical dating of single and multiple grains of quartz from Jinmium rockshelter, northern Australia: part I, experimental design and statistical models. Archaeometry 41: 339-364.

Gibbs, M. and Veth, P. (2002). Ritual engines and the archaeology of territorial ascendency (pp 11-19). In: Ulm, S., Westcott, C., Reid, J., Ross, A., Lilley, I., Prangnell, J. and Kirkwood, L. (eds), Barriers, Borders, Boundaries: Proceedings of the 2001 Australian Archaeological Association Annual Conference. Anthropology Museum, The University of Queensland: St Lucia, Australia.

Gould, R.A. (1968). Living archaeology: the Ngatatjara of Western Australia. Southwestern Journal of Anthropology 24(2): 101-122.

Gunn, R.G., Whear, R.L. and Douglas, L.C. (2010). A dingo burial from the Arnhem Land Plateau. Australian Archaeology 71: 11-16.

Gunn, R.G., Whear, R.L. and Douglas, L.C. (2012). A second recent canine burial from the Arnhem Land Plateau. Australian Archaeology 74: 103-105.

Haast, A. (n.d.). Walled Features in the Hamersley Plateau: Pilot Desktop Study. Unpublished report to BHP Billiton Iron Ore.

HEH - see Huonbrook Environment and Heritage.

Hogg, A., Turney, C., Palmer, J., Southon, J., Kromer, B., Bronk Ramsey, C., Boswijk, G., Fenwick, P., Noronha, A., Staff, R., Friedrich, M., Reynard, L., Guetter, D., Wacker, L. and Jones, R. (2013). The New Zealand Kauri (Agathis australis) Research Project: a radiocarbon dating intercomparison of Younger Dryas wood and implications for IntCal 13. Radiocarbon 55: 2035-2048.

Hook, F. and Di Lello, A. (2010). Gurdadaguji stone arrangements: late Holocene aggregation locals? [sic] (pp 285-297). In: Calado, D., Baldia, M. and Boulanger, M. (eds), Monumental Questions: Prehistoric Megaliths, Mounds and Enclosures. Archaeopress: Oxford.

Huonbrook Environment and Heritage (2012a). Test Excavations DIA Permit \# 453 A Deposit, Jirrpalpur Range, Mining Area $C$, the Pilbara. Unpublished report to BHP Billiton Iron Ore.

Huonbrook Environment and Heritage (2012b). Test Excavations DIA Permit \# 453 P3, Packsaddle Range, The Pilbara. Unpublished report to BHP Billiton Iron Ore.

Huonbrook Environment and Heritage (2013). Test Excavations DIA Permit \#453 P1 Deposit, Packsaddle Range, Mining Area C, The Pilbara. Unpublished reported to BHP Billiton Iron Ore.

Jackson, G. and Di Lello, A. (2003). A Report of an Assessment of 52 Previously Recorded Aboriginal Archaeological Sites in Hamersley Iron's Silvergrass and Homestead Project
Areas, near Brockman Detritals Mine, Pilbara, Western. Unpublished report to Pilbara Iron.

Jackson, G. and Martin, C. (2000). The Report of an Aboriginal Archaeological Survey of the Nammuldi Lens 'F' Survey Area, near Mt Brockman, Hamersley Plateau, Western Australia. Unpublished report to Hamersley Iron.

Jackson, G. and Fry, R. (2001). A Report of an Aboriginal Archaeological Survey of the Giles Exploration Drilling Program Area, (E47/539), near Newman, Western Australia. Unpublished report to Hamersley Iron.

Juluwarlu Aboriginal Corporation (n.d.). Wanggalili: Yindjibarndi and Ngarluma Plants. Juluwarlu Aboriginal Corporation: Roebourne, Australia.

Kimber, R.G. (1982). Some thoughts on stone arrangements. The Artefact 6: 10-18.

Law, W.B., Cropper, D.N. and Petchey, F. (2010). Djadjiling rockshelter: 35,000 C14 years of Aboriginal occupation in the Pilbara, Western Australia. Australian Archaeology 70: $68-71$.

Lewis, D. (1988). Hawk hunting hides in the Victoria River District. Australian Aboriginal Studies 1988(2): 74-78.

Love, J.R.B. (1936). Stone Age Bushmen of Today. Life and Adventure among a Tribe of Savages in North-Western Australia. Blackie and Son: London.

Marwick, B. (2002a). Millys Cave: evidence for human occupation of the inland Pilbara during the last glacial maximum (pp 21-33). In: Ulm, S., Westcott, C., Reid, J., Ross, A., Lilley, I., Prangnell, J. and Kirkwood, L. (eds), Barriers, Borders, Boundaries: Proceedings of the 2001 Australian Archaeological Association Annual Conference. Anthropology Museum, The University of Queensland: St Lucia, Australia.

Marwick, B. (2002b). Inland Pilbara Archaeology: A Study of Variation in Aboriginal Occupation over Time and Space on the Hamersley Plateau. Unpublished MA thesis, The University of Western Australia, Crawley, Australia.

Marwick, B. (2005). Element concentrations and magnetic susceptibility of anthrosols: indicators of prehistoric human occupation in the inland Pilbara, Western Australia. Journal of Archaeological Science 32: 1357-1368.

Mattner, J., Grguric, N., Larkin, E. and Pribac, C. (2014). Jindi Mine s.16 Test Excavations and Rockshelter Research, Central Pilbara, OB41 Project Area. Unpublished report to BHP Billiton Iron Ore.

Maynard, L. (1980). A Pleistocene date from an occupation deposit in the Pilbara region, Western Australia. Australian Archaeology 10: 3-8.

McCarthy, F.D. (1940). Aboriginal stone arrangements in Australia. The Australian Museum Magazine 2: 184-189.

McDonald, J. and Veth, P. (2009). Dampier Archipelago petroglyphs: archaeology, scientific values and National Heritage Listing. Archaeology in Oceania 44: 49-69.

McDonald, J. and Veth, P. (2013). Rock art in arid landscapes: Pilbara and Western Desert petroglyphs. Australian Archaeology 77: 66-81.

Memmott, P. (2007). Gunyah, Goodie and Wurley: The Aboriginal Architecture of Australia. University of Queensland Press: St Lucia, Australia.

Moore, P. (2005). A Guide to Plants of Inland Australia. Reed New Holland: Sydney.

Morse, K. (2009). Introduction. Emerging from the abyss archaeology in the Pilbara region of Western Australia. Archaeology in Oceania 44: 1-5. 
Mountford, C.P. (1940). Aboriginal stone structures. Transactions of the Royal Society of South Australia 64: 279-287.

Mulvaney, K. (1993). Hunting with hides: ethnohistorical reflections on Victoria River stone structures. Records of the South Australian Museum 26(2): 111-120.

Mulvaney, K. (1996). What to do on a rainy day: reminiscences of Mirriuwung and Gadjerong artists. Rock Art Research 13(1): $3-20$.

O'Connor, S. (1987). The stone house structures of High Cliffy Island, north-west Kimberley, Western Australia. Australian Archaeology 25: 30-39.

Olive, N. (ed.) (1997). Karinji Mirlimirli: Aboriginal Histories from the Pilbara. Fremantle Arts Centre Press: Fremantle, Australia.

Palmer, K. (1978). An Archaeological Survey of Aboriginal Sites in the West Angelas Area. Unpublished report to Cliffs International.

Pitman, H.T. and Wallis, L.A. (2012). The point of spinifex: a review of Aboriginal uses of spinifex grasses in Australia. Ethnobotanical Research and Applications 10: 109-131.

Prescott, J.R. and Hutton, J.T. (1994). Cosmic ray contributions to dose rates for luminescence and ESR dating: large depths and long-term time variations. Radiation Measurements 23: 497-500.

Slack, M. (2008). Report of Archaeological Survey and Excavation at the Proposed Brockman 4 Syncline Project, Pilbara Region, Western Australia. Unpublished report to Pilbara Iron.

Slack, M. (2014). The Nyiyaparli Research Project. Unpublished presentation in the University of Western Australia Archaeology Department Seminar Series, 14 August 2014.

Slack, M., Filios, M. and Fullagar, R. (2009). Aboriginal settlement during the LGM at Brockman, Pilbara region, Western Australia. Archaeology in Oceania 44: 32-39.

Smith, M. (2013). The Archaeology of Australia's Deserts. Cambridge University Press: New York.

Spencer, B. and Gillen, F.J. (1899). The Native Tribes of Central Australia. Macmillan: London.

Spencer, B. and Gillen, F.J. (1904). The Northern Tribes of Central Australia. Macmillan: London.

Spencer, B. and Gillen, F.J. (1927). The Arunta: A Study of a Stone Age People. Macmillan: London.

Strano, A. and Pervan, J. (2014). Salvage of Cultural Material within PlE, Mining Area C. Unpublished report to BHP Billiton Iron Ore.

Tindale, N.B. (1974). The Aboriginal Tribes of Australia. Australian National University Press: Canberra.

Troilett, G. (1982). Report on Ethel Gorge Salvage Project. Unpublished report to the Mt Newman Mining Company.

Veitch, B., Hook, F. and Bradshaw, E. (2005). A note on radiocarbon dates from the Paraburdoo, Mount Brockman and Yandicoogina areas of the Hamersley Plateau, Pilbara, Western Australia. Australian Archaeology 60: 58-61.

Veth, P. (1995). Aridity and settlement in northwest Australia. Antiquity 69: 733-746.

Veth, P. (2000). Origins of the Western Desert language: convergence in linguistic and archaeological space and time models. Archaeology in Oceania 35: 11-19.
Vinnicombe, P. (1987). Dampier Archaeological Project: Resource Document, Survey and Salvage of Aboriginal Sites, Burrup Peninsula, Western Australia. Western Australian Museum: Perth.

Wallis, L.A. (2001). Phytoliths, Late Quaternary Environment and Archaeology in Tropical Semi-arid Northwest Australia. Unpublished PhD thesis, Department of Archaeology and Natural History, Research School of Pacific and Asian Studies, The Australian National University, Canberra.

Wallis, L.A. (2003). An overview of phytolith production patterns in selected northwest Australian flora. Review of Palaeobotany and Palynology 125: 210-248.

Wallis, L.A. (2015). Findings from the Archaeological Investigation of Two Walled Rockshelters, Packsaddle Range, Pilbara. Unpublished report to BHP Billiton Iron Ore.

Wallis, L.A. and McBride, E. (2015). Preliminary Advice on the Sampling of Stick Nest Rat Middens, Central Pilbara, September 2015. Unpublished report to BHP Billiton Iron Ore.

Wallis, L.A. and Matthews, J. (2015). Investigations into the PIL_5968 and PIL_6001 Rockshelters in the Packsaddle 4 Deposit, Mining Area C, Pilbara. Unpublished report to BHP Billiton Iron Ore.

Wallis, L.A., Huntley, J., Watchman, A. and Ralph, J. (2015a). A Study of Painted Rock Art Sites in the Central Pilbara: Final Report. Unpublished report to BHP Billiton Iron Ore.

Wallis, L.A., Huntley, J. and Ralph, J. (2015b). Preliminary Advice on the Site Inspection and Study of Art Sites, Central Pilbara, June 2015. Unpublished report to BHP Billiton Iron Ore.

Warren, L. (2000). A Report of BHP Iron Ore's Archaeological and Ethnographic Surveys of the Mining Area $C$ and Section 18 and 16 Application Consultation (Interim Report October 2000). Unpublished report to BHPIO Aboriginal Affairs Department.

Westell, C. and Wood, V. (2012). An Archaeological Survey of Proposed Evaluation Drilling and Infrastructure Development Programs at Beasley River, Mount Farquhar, Boolgeeda and Mount Wall, Greater Brockman Region, Pilbara, Western Australia. Unpublished report to Rio Tinto Iron Ore.

Westell, C. and Wood, V. (2013). An Aboriginal Archaeological Survey of Proposed Evaluation Drilling and Track Development at Vivash, Mt Wall and Pinarra, Greater Brockman Region, Pilbara, Western Australia. Unpublished report to Rio Tinto Iron Ore.

Westell, C. and Wood, V. (2014). Aboriginal Archaeological Assessment of the Western Turner Syncline Phase 2 Expansion and Proposed RE Drilling Program, Pilbara, Western Australia. Unpublished report to Rio Tinto Iron Ore.

White, I. (ed.) (1985). Daisy Bates: The Native Tribes of Western Australia. National Library of Australia: Canberra.

Withnell, J.G. (1901). The Customs and Traditions of the Aboriginal Natives of North-Western Australia. Global Grey.

MANUSCRIPT RECEIVED 27 OCTOBER 2015; ACCEPTED 6 APRIL 2016. 